\title{
Global soil nitrous oxide emissions in a dynamic carbon-nitrogen model
}

\section{Y. Huang and S. Gerber}

Soil and Water Science Department, Institute of Food and Agricultural Sciences, University of Florida, Gainesville, Florida 32611, USA

Correspondence to: S. Gerber (sgerber@ufl.edu)

Received: 23 December 2014 - Published in Biogeosciences Discuss.: 11 February 2015

Revised: 9 October 2015 - Accepted: 14 October 2015 - Published: 10 November 2015

\begin{abstract}
Nitrous oxide $\left(\mathrm{N}_{2} \mathrm{O}\right)$ is an important greenhouse gas that also contributes to the depletion of stratospheric ozone. Due to its high temporal and spatial heterogeneity, a quantitative understanding of terrestrial $\mathrm{N}_{2} \mathrm{O}$ emission and its variabilities and responses to climate change are challenging. We added a soil $\mathrm{N}_{2} \mathrm{O}$ emission module to the dynamic global land model LM3V-N, and tested its sensitivity to mechanisms that affect the level of mineral nitrogen $(\mathrm{N})$ in soil such as plant $\mathrm{N}$ uptake, biological $\mathrm{N}$ fixation, amount of volatilized $\mathrm{N}$ redeposited after fire, and nitrification-denitrification. We further tested the relationship between $\mathrm{N}_{2} \mathrm{O}$ emission and soil moisture, and assessed responses to elevated $\mathrm{CO}_{2}$ and temperature. Results extracted from the corresponding gridcell (without site-specific forcing data) were comparable with the average of cross-site observed annual mean emissions, although differences remained across individual sites if stand-level measurements were representative of gridcell emissions. Processes, such as plant $\mathrm{N}$ uptake and $\mathrm{N}$ loss through fire volatilization that regulate $\mathrm{N}$ availability for nitrification-denitrification have strong controls on $\mathrm{N}_{2} \mathrm{O}$ fluxes in addition to the parameterization of $\mathrm{N}_{2} \mathrm{O}$ loss through nitrification and denitrification. Modelled $\mathrm{N}_{2} \mathrm{O}$ fluxes were highly sensitive to waterfilled pore space (WFPS), with a global sensitivity of approximately $0.25 \mathrm{TgN}$ per year per 0.01 change in WFPS. We found that the global response of $\mathrm{N}_{2} \mathrm{O}$ emission to $\mathrm{CO}_{2}$ fertilization was largely determined by the response of tropical emissions with reduced $\mathrm{N}_{2} \mathrm{O}$ fluxes in the first few decades and increases afterwards. The initial reduction was linked to $\mathrm{N}$ limitation under higher $\mathrm{CO}_{2}$ level, and was alleviated through feedbacks such as biological $\mathrm{N}$ fixation. The extratropical response was weaker and generally positive, high-
\end{abstract}

lighting the need to expand field studies in tropical ecosystems. We did not find synergistic effects between warming and $\mathrm{CO}_{2}$ increase as reported in analyses with different models. Warming generally enhanced $\mathrm{N}_{2} \mathrm{O}$ efflux and the enhancement was greatly dampened when combined with elevated $\mathrm{CO}_{2}$, although $\mathrm{CO}_{2}$ alone had a small effect. The differential response in the tropics compared to extratropics with respect to magnitude and sign suggests caution when extrapolating from current field $\mathrm{CO}_{2}$ enrichment and warming studies to the globe.

\section{Introduction}

Nitrous oxide $\left(\mathrm{N}_{2} \mathrm{O}\right)$ is a major reactant in depleting stratospheric ozone as well as an important greenhouse gas (Ravishankara et al., 2009; Butterbach-Bahl et al., 2013; Ciais et al., 2013). With a global warming potential of 298 times more (per unit mass) than that of carbon dioxide $\left(\mathrm{CO}_{2}\right)$ over a 100-year period (Forster et al., 2007), the contributions of $\mathrm{N}_{2} \mathrm{O}$ emissions to global radiative forcing and climate change are of critical concern (Zaehle and Dalmonech, 2011). The concentration of atmospheric $\mathrm{N}_{2} \mathrm{O}$ has been increasing considerably since the industrial revolution with a linear rate of $0.73 \pm 0.03 \mathrm{ppb} \mathrm{yr}^{-1}$ over the last 3 decades (Ciais et al., 2013). Although applications of synthetic fertilizer and manure during agriculture intensification have been identified as the major causes of this increase (Davidson, 2009; Zaehle and Dalmonech, 2011; Zaehle et al., 2011), nonagricultural (natural) soil is still an important $\mathrm{N}_{2} \mathrm{O}$ source (Ciais et al., 2013; Syakila and Kroeze, 2011). $\mathrm{N}_{2} \mathrm{O}$ fluxes from nonagricultural soils are highly heterogeneous, which limits our abil- 
ity to estimate and predict global scale budgets, and quantify the response of natural $\mathrm{N}_{2} \mathrm{O}$ fluxes to global environmental changes (Butterbach-Bahl et al., 2013; Ciais et al., 2013).

Most of the $\mathrm{N}_{2} \mathrm{O}$ fluxes from soil are produced by microbial nitrification and denitrification (Braker and Conrad, 2011; Syakila and Kroeze, 2011). Nitrification is an aerobic process that oxidizes ammonium $\left(\mathrm{NH}_{4}^{+}\right)$to nitrate $\left(\mathrm{NO}_{3}^{-}\right)$, during which some $\mathrm{N}$ is lost as $\mathrm{N}_{2} \mathrm{O}$. Denitrification reduces nitrate or nitrite to gaseous $\mathrm{N}$ (i.e. $\mathrm{NO}_{x}, \mathrm{~N}_{2} \mathrm{O}$ and $\mathrm{N}_{2}$ ), a process that is fostered under anaerobic conditions. During denitrification $\mathrm{N}_{2} \mathrm{O}$ is generated in intermediary steps where a small portion can escape from the soil before further reduction to $\mathrm{N}_{2}$ takes place. Soil texture, soil $\mathrm{NH}_{4}^{+}$, soil waterfilled pore space (WFPS), mineralization rate, soil $\mathrm{pH}$, and soil temperature are well-known regulators of nitrification $\mathrm{N}_{2} \mathrm{O}$ fluxes (Parton et al., 1996; Li et al., 2000; Parton et al., 2001). Denitrification and associated $\mathrm{N}_{2} \mathrm{O}$ emissions depend primarily on carbon supply, the redox potential and soil $\mathrm{NO}_{3}^{-}$(Firestone and Davidson, 1989; Parton et al., 1996). Soil moisture has a particularly strong impact (Galloway et al., 2003; Schlesinger, 2009) as it influences nitrification and denitrification rates through its regulations on substrate availability and soil redox potential (oxygen diffusion proceeds at a much slower rate in water-filled than in air-filled pore space), thereby also controlling the partitioning among various denitrification products (i.e. $\mathrm{NO}_{x}, \mathrm{~N}_{2} \mathrm{O}$ and $\mathrm{N}_{2}$; Firestone and Davidson, 1989; Parton et al., 2001). Although emissions are known to be sensitive to soil moisture, quantitative understanding of its role in terrestrial $\mathrm{N}_{2} \mathrm{O}$ fluxes and variability is limited (Ciais et al., 2013).

At regional to global scale, the application of the "hole-inpipe" concept (Firestone and Davidson, 1989) in the CASA biosphere model pioneered one of the earliest process-based estimation of natural soil $\mathrm{N}_{2} \mathrm{O}$ fluxes. The model calculated the sum of $\mathrm{NO}_{x}, \mathrm{~N}_{2} \mathrm{O}$ and $\mathrm{N}_{2}$ fluxes as a constant portion of gross mineralized $\mathrm{N}$, and the relative ratios of $\mathrm{N}$ trace gases $\left(\mathrm{NO}_{x}: \mathrm{N}_{2} \mathrm{O}: \mathrm{N}_{2}\right)$ as a function of soil moisture (Potter et al., 1996). While the early models of nitrification and denitrification are primarily conceptual-driven, recent global $\mathrm{N}_{2} \mathrm{O}$ models combine advancements in global dynamic land models with more detailed processes, including microbial dynamics. Xu-Ri and Prentice (2008) simplified nitrification and denitrification modules from DNDC (i.e., Denitrification-Decomposition; Li et al., 1992, 2000) in their global scale dynamic $\mathrm{N}$ scheme (DyN) and incorporated DyN into the LPJ dynamic global vegetation model. In the DNDC approach, nitrification and denitrification were allowed to occur simultaneously in aerobic and anaerobic microsites. Zaehle et al. (2011) incorporated a nitrificationdenitrification scheme into the O-CN land model following largely the LPJ-DyN with minor modifications and additions of the effects of soil $\mathrm{pH}$ and chemo-denitrification that originated from DNDC (Li et al., 2000). Stocker et al. (2013) embedded the LPJ-DyN approach into an Earth System Model and investigated the feedback of $\mathrm{N}_{2} \mathrm{O}$ emissions, together with $\mathrm{CO}_{2}$ and $\mathrm{CH}_{4}$, to climate. Compared to the LPJ-DyN approach, Saikawa et al. (2013) retained the explicit simulation of nitrifying and denitrifying bacteria from DNDC in their CLMCN-N2O module based on the CLM V3.5 land model. Simulations with O-CN demonstrated a positive response of $\mathrm{N}_{2} \mathrm{O}$ emissions to historical warming and a negative response to historical $\mathrm{CO}_{2}$ increase, globally. While $\mathrm{CO}_{2}$ and interaction with climate change resulted in an increase in historical and future $\mathrm{N}_{2} \mathrm{O}$ emissions in LPJ-DyN (Xu-Ri et al., 2012) and its application in LPX-Bern (Stocker et al., 2013), respectively, historical $\mathrm{CO}_{2}$ change alone, i.e. single factor of Xu-Ri et al. (2012), caused a slight decrease in historical $\mathrm{N}_{2} \mathrm{O}$ emissions. The negative $\mathrm{CO}_{2}$ response seems to be in disagreement with one meta-analysis of manipulative field experiments showing an increase in $\mathrm{N}_{2} \mathrm{O}$ emissions at elevated levels of $\mathrm{CO}_{2}$ (Zaehle et al., 2011; Xu-Ri et al., 2012; van Groenigen et al., 2011). The discrepancy in response to global change factors needs to be addressed both in models and in the interpretation of manipulative field experiments.

Here we add an $\mathrm{N}_{2} \mathrm{O}$ gas emission module to LM3V-N, a land model developed at the Geophysical Fluid Dynamics Laboratory (GFDL). In this paper, we will first briefly introduce LM3V-N and describe the added $\mathrm{N}_{2} \mathrm{O}$ emission module. We then subject the model to historic changes in $\mathrm{CO}_{2}$, $\mathrm{N}$ deposition, and recent climate change to infer natural $\mathrm{N}_{2} \mathrm{O}$ emissions in the past few decades. We test the model's sensitivity to soil water regime, by addressing the parameterization of soil WFPS, and by replacing the model soil moisture with two different soil moisture reanalysis products. We also conduct sensitivity tests with regard to the general $\mathrm{N}$ cycling and parameterization of $\mathrm{N}_{2} \mathrm{O}$ emissions. We then subject the model to step changes in atmospheric $\mathrm{CO}_{2}$ and temperature to understand modelled responses to $\mathrm{CO}_{2}$ fertilization and climate change. Since we build largely on existing parameterization of nitrification-denitrification processes, we will briefly discuss implications from transferring process formulations to LM3V-N where other aspects of the $\mathrm{N}$ cycle are treated differently.

\section{Methods}

\subsection{Model description}

LM3V is capable of simulating ecosystem dynamics and exchange of $\mathrm{CO}_{2}$, water and energy between land and atmosphere with the fastest time step of $30 \mathrm{~min}$ (Shevliakova et al., 2009). LM3V-N expands the LM3V land model with a prognostic $\mathrm{N}$ cycle (Gerber et al., 2010), and includes five plant functional types (PFTs): C3 and C4 grasses, tropical, temperate deciduous and cold evergreen trees. Each PFT has five vegetation $\mathrm{C}$ pools (leaf, fine root, sapwood, labile, and wood), two litter and two soil organic $\mathrm{C}$ pools and their corresponding $\mathrm{N}$ pools based on the specific $\mathrm{C}: \mathrm{N}$ ratios. Photo- 
synthesis is coupled with stomatal conductance on the basis of Collatz et al.'s (1991, 1992) simplification of the Farquhar scheme (Farquhar et al., 1980). Soil hydrology in LM3V-N follows partly on Land Dynamics (LaD) with further improvements (Shevliakova et al., 2009; Milly and Shmakin, 2002; Milly et al., 2014). N enters the ecosystem through atmospheric $\mathrm{N}$ deposition and biological $\mathrm{N}$ fixation (BNF), losses via fire and leaching of dissolved organic N (DON) as well as mineral $\mathrm{N}$. We briefly describe the major characteristics of LM3V-N in the next Sect. 2.1.1, and details are available in Gerber et al. (2010).

\subsubsection{Main characteristic of LM3V-N}

\section{$\mathrm{C}-\mathrm{N}$ coupling in vegetation}

We briefly describe the larger plant-soil $\mathrm{N}$ cycle and how it links to mineral $\mathrm{N}$ (ammonium and nitrate). Plants adjust their uptake of $\mathrm{C}$ and $\mathrm{N}$ to maintain their tissue-specific $\mathrm{C}: \mathrm{N}$ ratios, which are PFT-dependent constants. Instead of varying $\mathrm{C}: \mathrm{N}$ ratios in tissues, short-term asynchronies in $\mathrm{C}$ and $\mathrm{N}$ assimilations or temporary imbalances in stoichiometry are buffered by an additional $\mathrm{N}$ storage pool $(S)$ in which $\mathrm{N}$ is allowed to accumulate once plant $\mathrm{N}$ demand is satisfied. The optimum storage size $S_{\text {target }}$ is based on tissue turnover $Q_{\mathrm{N}, \text { liv }}$,

$S_{\text {target }}=t_{\mathrm{h}} Q_{\mathrm{N}, \text { liv }}$,

where $t_{\mathrm{h}}$ is the time span that buffers plant $\mathrm{N}$ losses (currently set as 1 year). Plant $\mathrm{N}$ status $(x)$ is defined as the fraction of the actual $\mathrm{N}$ storage compared to the target storage: $x=$ $S / S_{\text {target }}$. Consequently, $\mathrm{N}$ constraints on photosynthesis and soil $\mathrm{N}$ assimilation are based on plant $\mathrm{N}$ status:

$A_{\mathrm{g}, \mathrm{N}}=A_{\mathrm{g}, \text { pot }}\left(1-e^{-x \varphi}\right)$
$U_{\mathrm{N}, \mathrm{P}}=U_{\mathrm{N}, \mathrm{P}, \text { pot }} \cdot \begin{cases}1 & \text { if } S<S_{\text {target }} \\ 0 & \text { else }\end{cases}$

where $A_{\mathrm{g}, \mathrm{N}}$ indicates $\mathrm{N}$ constrained rate of gross photosynthesis $\left(\mu \mathrm{molC} \mathrm{m}{ }^{-2} \mathrm{~s}^{-1}\right.$ ) and $A_{\mathrm{g}}$, pot corresponds to the potential photosynthetic rate without $\mathrm{N}$ limitation. The parameter $\varphi$ mimics the metabolic deficiency as plant $\mathrm{N}$ decreases. $U_{\mathrm{N}, \mathrm{P} \text {, pot }}$ is the potential inorganic $\mathrm{N}$ uptake rate from soil available ammonium and nitrate pools. The actual inorganic $\mathrm{N}$ uptake rate $\left(U_{\mathrm{N}, \mathrm{P}}\right)$ operates at its potential if plants are $\mathrm{N}$ limited and drops to zero when $\mathrm{N}$ storage $(S)$ reaches its target size. Overall this set-up intends to overcome short-term asynchronies between $\mathrm{C}$ and $\mathrm{N}$ supply.

\section{Soil C-N interactions in organic matter decomposition}

Organic matter decomposition is based on a modified CENTURY approach (Bolker et al., 1998), and amended with formulations of $\mathrm{N}$ dependent $\mathrm{C}$ and $\mathrm{N}$ mineralization rates. Here, we use a 3-pool model where the pools broadly represent labile and structural litter, and processed soil organic matter. Decomposition is the main source of available $\mathrm{N}$ for nitrification and denitrification. In turn, $\mathrm{NO}_{3}^{-}$and $\mathrm{NH}_{4}^{+}$can both trigger the decomposition of "light" organic matter and stabilize C in "heavy" organic matter in LM3V-N. Formation of a slow decomposable organic matter pool leads to immobilization of ammonium and nitrate to satisfy the fixed carbon to nitrogen ratio of this pool.

\section{Competing sinks of available $\mathbf{N}$}

The fate of soil mineral $\mathrm{N}$ (i.e. ammonium and nitrate) depends on the relative strength of the competing sinks, with the broad hierarchy of sorption $>$ soil immobilization $>$ plant uptake $>$ leaching/denitrification. This creates a tight $\mathrm{N}$ cycle, since internal (plant and soil) sinks dominate over $\mathrm{N}$ losses. Denitrification thus far has been lumped with leaching losses and summed into a generic N loss term. Sorption/desorption buffers available $\mathrm{N}$ and is assumed to have the highest priority and be at steady state in each model time step. $\mathrm{N}$ immobilization into organic matter occurs during transfers among litter and soil organic matter pools. Leaching losses of available $\mathrm{N}$ are simulated on the basis of drainage rate. Plant uptake of mineral $\mathrm{N}$ is a combination of both active and passive processes. The active uptake is modelled as a Monod function, and the passive transport is a function of available $\mathrm{N}$ and plant transpiration:

$U_{\mathrm{N}, \mathrm{P}, \operatorname{pot}, i}=\frac{v_{\mathrm{max}} \mathrm{C}_{\mathrm{r}} \mathrm{N}_{i, \mathrm{av}}}{h_{\mathrm{s}}\left(k_{\mathrm{p}, 1 / 2}+\left[\mathrm{N}_{\mathrm{av}}\right]\right)}+\left[\mathrm{N}_{i, \mathrm{av}}\right] Q_{\mathrm{W}, \mathrm{T}}$,

where $v_{\max }\left(\mathrm{yr}^{-1} \mathrm{kgC}^{-1}\right)$ stands for the maximum uptake rate per unit root mass $\mathrm{C}_{\mathrm{r}}, h_{\mathrm{s}}$ is soil depth, $k_{\mathrm{p}, 1 / 2}$ is the half saturation constant, and $Q_{\mathrm{W}, \mathrm{T}}$ represents the transpiration flux of water. The subscript $i$ refers to either ammonium or nitrate, while $\left[\mathrm{N}_{\mathrm{av}}\right]$ is the concentration of the combined dissolved ammonium nitrate pool. Potential uptake and thus effective removal of available $\mathrm{N}$ occurs if plants are $\mathrm{N}$ limited (see Eq. 3).

\section{N losses from organic pools}

With the implementation of high ecosystem $\mathrm{N}$ retention under limiting conditions where internal $\mathrm{N}$ sinks outcompeting losses from the ammonium/nitrate pools, losses via organic pathways become important (Gerber et al., 2010; Thomas et al., 2015). Over the long term, $\mathrm{N}$ losses via fire and DON are thus critical factors limiting ecosystem $\mathrm{N}$ accumulation and maintaining $\mathrm{N}$ limitation in LM3V-N. $\mathrm{N}$ volatilized via fire is approximated as a function of $\mathrm{CO}_{2}$ produced in a fire, stoichiometric ratio of burned tissues but reduced by a global retention factor representing the fraction of $\mathrm{N}$ that is retained as ash (ash_fraction, currently set as 0.45). DON leaching is linked to hydrologic losses of dissolved organic matter ( $\left.L_{\mathrm{DOM}}\right)$ and its $\mathrm{C}: \mathrm{N}$ ratio. In turn $L_{\mathrm{DOM}}$ is based on drainage rate $\left(Q_{\mathrm{W}, \mathrm{D}}\right)$ and a buffer or sorption parameter $b_{\mathrm{DOM}}$ (cur- 
rently set as 20).

$L_{\mathrm{DOM}}=\frac{Q_{\mathrm{W}, \mathrm{D}}}{h_{\mathrm{s}} b_{\mathrm{DOM}}} \mathrm{DOM}$,

where DOM is the amount of dissolve organic matter in the soil column. Soil depth $\left(h_{\mathrm{s}}\right)$ is used to convert DOM unit to concentration (in unit of $\mathrm{kgC} \mathrm{m}^{-3}$ ). Production of DOM (in unit of $\mathrm{kgC} \mathrm{m}^{-2} \mathrm{yr}^{-1}$ ) is assumed to be proportional to the decomposition flux of the structural litter and soil water content. Both, losses via fire and via DOM are losses from a plant-unavailable pool (Thomas et al., 2015), and have the potential to increase or maintain $\mathrm{N}$ limitation over longer timescales, and consequently reduce $\mathrm{N}$ availability for $\mathrm{N}_{2} \mathrm{O}$ production through sustained and strong plant $\mathrm{N}$ uptake.

\section{Biological nitrogen fixation (BNF)}

BNF in LM3V-N is dynamically simulated on the basis of plant $\mathrm{N}$ availability, $\mathrm{N}$ demand, and light condition. BNF increases if plant $\mathrm{N}$ requirements are not met by uptake. The rate of up-regulation is swift for tropical trees but constrained by light penetrating the canopy for other PFTs, mimicking the higher light requirements for new recruits that possibly can convert atmospheric $\mathrm{N}_{2}$ into plant available forms. In turn, sufficient $\mathrm{N}$ uptake reduces BNF. The BNF parameterization thus creates a negative feedback, where high plant available $\mathrm{N}$ and thus the potential for denitrification is counteracted with reduction of $\mathrm{N}$ input into the plant-soil system. This explicit negative feedback is different to other models where BNF is parameterized based on NPP (Thornton et al., 2007) or transpiration (Smith et al., 2014). The inclusion of $\mathrm{BNF}$ as a negative feedback contributes to a rather tight cycling within LM3V-N, with low overall rates of BNF under unperturbed conditions (Gerber et al., 2013).

\section{Soil $\mathrm{N}_{2} \mathrm{O}$ emission}

LM3V-N assumes that nitrification is linearly scaled to ammonium content, and modified by soil temperature and soil moisture. Gaseous losses so far were not differentiated from hydrological leaching. We add a soil nitrificationdenitrification module which accounts for $\mathrm{N}$ gaseous losses from $\mathrm{NH}_{3}$ volatilization, nitrification and denitrification. The nitrification-denitrification scheme implemented here combines features from both the DNDC model (Li et al., 1992, 2000) and the CENTURY/DAYCENT model (Parton et al., 1996, 2001; Del Grosso et al., 2000). In this subsection, we provide details on the nitrification-denitrification module which explicitly simulates $\mathrm{N}$ gas losses via nitrification and denitrification, as well as other process modifications compared to the original LM3V-N.

\section{Nitrification-Denitrification}

Transformation among mineral $\mathrm{N}$ species (ammonium and nitrate) occurs mainly through two microbial pathways: nitri- fication and denitrification. Although ongoing debate exists in whether nitrification rates may be well described by bulk soil ammonium concentration or soil $\mathrm{N}$ turnover rate (Parton et al., 1996; Zaehle and Dalmonech, 2011), we adopt the donor-controlled scheme (ammonium concentration). In addition to substrate, soil texture, soil water-filled pore space (WFPS, the fraction of soil pore space filled with water), and soil temperature are all well-known regulators of nitrification. As a first order approximation, nitrification rate $(N$, in unit, $\mathrm{kgN} \mathrm{m}^{-2} \mathrm{yr}^{-1}$ ) is simulated as a function of soil temperature, $\mathrm{NH}_{4}^{+}$availability and WFPS,

$N=k_{\mathrm{n}} f_{\mathrm{n}}(T) f_{\mathrm{n}}($ WFPS $) \frac{N_{\mathrm{NH}_{4}^{+}}}{b_{\mathrm{NH}_{4}^{+}}}$

where $k_{\mathrm{n}}$ is the base nitrification rate $\left(11000 \mathrm{yr}^{-1}\right.$, the same as in LM3V-N; Gerber et al., 2010); $N_{\mathrm{NH}_{4}^{+}}$is ammonium content (in unit, $\mathrm{kgN} \mathrm{m}^{-2}$ ); $b_{\mathrm{NH}_{4}^{+}}$is the buffer or sorption parameter for $\mathrm{NH}_{4}^{+}$(unitless, 10 in LM3V-N; Gerber et al., 2010); $f_{\mathrm{n}}(T)$ is the temperature response function following $\mathrm{Li}$ et al. (2000), with an optimum temperature for nitrification at $35^{\circ} \mathrm{C}$; and $f_{\mathrm{n}}$ (WFPS) is the soil water response function. The effect of WFPS on nitrification is texture dependent, with most of the reported optimum value around 0.6 (Parton et al., 1996; Linn and Doran, 1984). We adopt the empirical WFPS response function from Parton et al. (1996) with medium soil texture.

$$
\begin{aligned}
& f_{\mathrm{n}}(T)=\left(\frac{60-T_{\text {soil }}}{25.78}\right)^{3.503} \times e^{\frac{3.503 \times\left(T_{\text {soil }}-34.22\right)}{25.78}} \\
& f_{\mathrm{n}}(\text { WFPS })=\left(\frac{\text { WFPS }-1.27}{-0.67}\right)^{\frac{1.9028}{0.59988}} \\
& \cdot\left(\frac{\text { WFPS }-0.0012}{0.59988}\right)^{2.84}
\end{aligned}
$$

where $T_{\text {soil }}$ is the soil temperature in ${ }^{\circ} \mathrm{C}$.

Denitrification is controlled by substrate $\mathrm{NO}_{3}^{-}$(electron acceptor), labile $\mathrm{C}$ availability (electron donor), soil moisture and temperature. Labile $\mathrm{C}$ availability is estimated by soil heterotrophic respiration (HR). Following LPJ-DyN (Xu-Ri and Prentice, 2008), denitrification is assumed to have a $Q_{10}$ value of 2 when the soil temperature is between 15 and $25^{\circ} \mathrm{C}$. The soil moisture response function is adopted from Parton et al. (1996). Soil pH is reported to be an important indicator of chemodenitrification which occurs predominantly in acidic soils $(\mathrm{pH}<5)$ under conditions of high nitrite concentration ( $\mathrm{Li}$ et al., 2000). However, its role for $\mathrm{N}_{2} \mathrm{O}$ production is not well studied (Li et al., 2000) and we do not model chemodenitrification explicitly.

$D=k_{\mathrm{d}} f_{\mathrm{d}}(T) f_{\mathrm{d}}($ WFPS $) f_{\mathrm{g}} \mathrm{NO}_{3}^{-}$ 
and

$f_{\mathrm{g}}=\frac{\mathrm{HR}}{\mathrm{HR}+K_{\mathrm{c}}} \frac{\mathrm{NO}_{3}^{-}}{\mathrm{NO}_{3}^{-}+K_{\mathrm{n}}}$

$\mathrm{NO}_{3}^{-}=\frac{N_{\mathrm{NO}_{3}^{-}}}{b_{\mathrm{NO}_{3}^{-}}}$

where $D$ is the denitrification rate (in unit, $\mathrm{kgN} \mathrm{m}^{-2} \mathrm{yr}^{-1}$ ); $k_{\mathrm{d}}$ is the base denitrification rate $\left(8750 \mathrm{yr}^{-1}\right) ; f_{\mathrm{g}}$ mimics the impact of labile $\mathrm{C}$ availability and substrate (nitrate) on the growth of denitrifiers, adapted from Li et al. (2000); $K_{\mathrm{c}}$ and $K_{\mathrm{n}}$ are half-saturation constants taken from Li et al. (2000; 0.0017 and $0.0083 \mathrm{kgN} \mathrm{m}^{-2}$ respectively, assuming an effective soil depth of $0.1 \mathrm{~m}) ; b_{\mathrm{NO}_{3}^{-}}$is the buffer or sorption parameter for $\mathrm{NO}_{3}^{-}$(unitless, 1 in LM3V-N; Gerber et al., 2010); $N_{\mathrm{NO}_{3}^{-}}$and $\mathrm{NO}_{3}^{-}$are nitrate content before and after being buffered (in unit, $\mathrm{kgN} \mathrm{m}^{-2}$ ), respectively; and $f_{\mathrm{d}}(T)$ and $f_{\mathrm{d}}$ (WFPS) are empirical soil temperature and water response function for denitrification, adopted from $\mathrm{Xu}-\mathrm{Ri}$ and Prentice (2008) and Parton et al. (1996), respectively.

$$
\begin{aligned}
& f_{\mathrm{d}}(T)=e^{308.56 \times\left(\frac{1}{68.02}-\frac{1}{T_{\text {soil }}+46.02}\right)} \\
& f_{\mathrm{d}}(\mathrm{WFPS})=\frac{1.56}{12.0\left(\frac{16.0}{12.0^{(2.01 \times \mathrm{WFPS})}}\right)}
\end{aligned}
$$

\section{Gaseous partitions from nitrification-denitrification}

$\mathrm{N}_{2} \mathrm{O}$ is released as a byproduct during both nitrification and denitrification. The fraction of $\mathrm{N}_{2} \mathrm{O}$ lost during net nitrification is uncertain ( $\mathrm{Li}$ et al., 2000; Xu-Ri and Prentice, 2008). Here we set this fraction to be $0.4 \%$, which is higher than Goodroad and Keeney (1984), but at the low end provided by Khalil et al. (2004). Nitrification also generates $\mathrm{NO}_{x}$ gas, in addition to $\mathrm{N}_{2} \mathrm{O}$. $\mathrm{N}$ losses as $\mathrm{NO}_{x}$ emissions during nitrification are scaled to the $\mathrm{N}_{2} \mathrm{O}$ release using a variable $\mathrm{NO}_{x}: \mathrm{N}_{2} \mathrm{O}$ ratio $\left(R_{\mathrm{NO}_{x}: \mathrm{N}_{2} \mathrm{O}}\right) . R_{\mathrm{NO}_{x}: \mathrm{N}_{2} \mathrm{O}}$ varies with relative gas diffusivity $\left(D_{\mathrm{r}}\right.$, the relative gas diffusivity in soil compared to air; Parton et al., 2001), which is calculated from air-filled porosity (AFPS, i.e., the portion of soil pore space that is filled by air; Davidson and Trumbore, 1995)

$$
\begin{aligned}
& R_{\mathrm{NO}_{x}: \mathrm{N}_{2} \mathrm{O}}=15.2+\frac{35.5 \times \operatorname{ATAN}\left[0.68 \times \pi \times\left(10 \times D_{\mathrm{r}}-1.68\right)\right]}{\pi} \\
& D_{\mathrm{r}}=0.209 \times \mathrm{AFPS}^{\frac{4}{3}}
\end{aligned}
$$

where ATAN stands for the trigonometric arctangent function; AFPS is the air-filled porosity (1-WFPS), and $\pi$ is the mathematical constant, approximately 3.14159 .

During denitrification, the gaseous ratio between $\mathrm{N}_{2}$ and $\mathrm{N}_{2} \mathrm{O}\left(R_{\mathrm{N}_{2}: \mathrm{N}_{2} \mathrm{O}}\right)$ is calculated following the empirical function derived by Del Grosso et al. (2000), which combines the effects of substrate $\left(\mathrm{NO}_{3}^{-}\right)$to electron donor ( $\mathrm{HR}$, the proxy for labile C) ratio and WFPS. $R_{\mathrm{N}_{2}: \mathrm{N}_{2} \mathrm{O}}$ is updated at every time step and for each grid cell.

$$
R_{\mathrm{N}_{2}: \mathrm{N}_{2} \mathrm{O}}=\operatorname{Fr}\left(\frac{\mathrm{NO}_{3}^{-}}{\mathrm{HR}}\right) \cdot \operatorname{Fr}(\mathrm{WFPS})
$$

with

$$
\operatorname{Fr}\left(\frac{\mathrm{NO}_{3}^{-}}{\mathrm{HR}}\right)=\max \left(0.16 \times k, k \times e^{\left(-0.8 \times \frac{\mathrm{NO}_{3}^{-}}{\mathrm{HR}}\right)}\right)
$$

$\operatorname{Fr}(\mathrm{WFPS})=\max (0.1,0.015 \times \mathrm{WFPS}-0.32)$

where $k$ is a texture-dependent parameter (Table 1) estimated from Del Grosso et al. (2000). $k$ controls the maximum value of the function $\mathrm{Fr}\left(\frac{\mathrm{NO}_{3}^{-}}{\mathrm{HR}}\right)$.

\section{Other modified processes}

To complete the $\mathrm{N}$ loss scheme, we also added $\mathrm{NH}_{3}$ volatilization into $\mathrm{LM} 3 \mathrm{~V}-\mathrm{N}$. $\mathrm{NH}_{3}$ volatilization in soil results from the difference between the equilibrium $\mathrm{NH}_{3}$ partial pressure in soil solution and that in the air. Dissolved $\mathrm{NH}_{3}$ is regulated by ammonium concentration and $\mathrm{pH}$. The net flux of $\mathrm{NH}_{3}$ from soil to the atmosphere varies with soil $\mathrm{NH}_{3}$, moisture, temperature, therefore

$\mathrm{NH}_{3}=k_{\mathrm{nh}} f(\mathrm{pH}) f_{\mathrm{NH}_{3}}(T)(1-$ WFPS $) \frac{\mathrm{NH}_{4}^{+}}{b_{\mathrm{NH}_{4}^{+}}}$

where $\mathrm{NH}_{3}$ is the net ammonia volatilization flux (in unit, $\left.\mathrm{kgN} \mathrm{m}^{-2} \mathrm{yr}^{-1}\right) ; k_{\mathrm{nh}}$ is the base ammonia volatilization rate $\left(365 \mathrm{yr}^{-1}\right) ; f(\mathrm{pH})$ is the $\mathrm{pH}$ factor and $f_{\mathrm{NH}_{3}}(T)$ is the temperature factor which are given by the following two equations:

$$
\begin{aligned}
& f(\mathrm{pH})=e^{2 \times\left(\mathrm{pH}_{\text {soil }}-10\right)} \\
& f_{\mathrm{NH}_{3}}(T)=\min \left(1, e^{308.56 \times\left(\frac{1}{71.02}-\frac{1}{T_{\text {soil }}+46.02}\right)}\right),
\end{aligned}
$$

where $\mathrm{pH}_{\text {soil }}$ is the soil $\mathrm{pH}$ which is prescribed instead of simulated dynamically. $f(\mathrm{pH})$ and $f_{\mathrm{NH}_{3}}(T)$ follow largely on the $\mathrm{NH}_{3}$ volatilization scheme implemented in the dynamic global vegetation model LPJ-DyN (Xu-Ri and Prentice, 2008).

\subsection{Model experiments}

\subsubsection{Global hindcast with potential vegetation}

To understand the model performance and compare with other models and observations, we conducted a hindcast simulation with potential vegetation. The model resolution was set to $3.75^{\circ}$ longitude by $2.5^{\circ}$ latitude. We forced the model with $3 \mathrm{~h}$ reanalysis weather data based on Sheffield et al. (2006). We used a 17-year recycled climate of 1948-1964 
Table 1. Texture-dependent parameter $k$, which partitions $\mathrm{N}_{2} \mathrm{O} / \mathrm{N}_{2}$ gas fractions during denitrification, estimated from Del Grosso et al. (2000).

\begin{tabular}{lrrrrrrrr}
\hline $\begin{array}{l}\text { Soil } \\
\text { Texture }\end{array}$ & Coarse & Medium & $\begin{array}{r}\text { Fine } \\
\text { medium }\end{array}$ & $\begin{array}{r}\text { Coarse } \\
\text { fine }\end{array}$ & $\begin{array}{r}\text { Coarse/ } \\
\text { fine }\end{array}$ & $\begin{array}{r}\text { Medium/ } \\
\text { medium/fine }\end{array}$ & Coarse/ & Organic \\
\hline$k$ & 2 & 10 & 22 & 6 & 12 & 16 & 11 & 2 \\
\hline
\end{tabular}

for the spin-up and simulation years prior to 1948. Atmospheric $\mathrm{CO}_{2}$ concentration was prescribed with $284 \mathrm{ppm}$ for model spin-up and based on ice core and atmospheric measurements for transient simulations (Keeling et al., 2009). N deposition was set as natural background for simulations before 1850 (Dentener and Crutzen, 1994), and interpolated linearly between the natural background and a snapshot of contemporary (1995) deposition (Dentener et al., 2006) for simulations after 1850 . Soil $\mathrm{pH}$ was prescribed and derived from the Harmonized World Soil Database (HWSD) version 1.1, the same as NACP model driver data (Wei et al., 2014).

The model was spun up from bare ground without $\mathrm{C}-\mathrm{N}$ interactions for the first 68 years and with $\mathrm{C}-\mathrm{N}$ interactions for the following 1200 years to develop and equilibrate $\mathrm{C}$ and $\mathrm{N}$ stocks. To accelerate the spin-up process, slow litter and soil $\mathrm{C}$ and $\mathrm{N}$ pools were set to the equilibrium values based on litterfall inputs and decomposition/leaching rates every 17 years. We determined the model to reach a quasi-equilibrium state by confirming the drift to be less than $0.03 \mathrm{PgC} \mathrm{yr}^{-1}$ for global C storage and $0.2 \mathrm{TgN} \mathrm{yr}^{-1}$ for global $\mathrm{N}$ storage. From this quasi-equilibrium state, we initialized the global hindcast experiment starting from 1850 using the corresponding climatic forcings, $\mathrm{CO}_{2}$ and $\mathrm{N}$ deposition data. In the following analysis, we will focus mostly on the last 3 decades (1970-2005).

\subsubsection{Sensitivity to soil water-filled pore space (WFPS)}

While LM3V-N carries a simplified hydrology, we bracketed effects of soil moisture by exploring the paremeterization of WFPS and by substituting the predicted soil moisture with 3hourly re-analysis data. Levels of soil water (in unit $\mathrm{kg} \mathrm{m}^{-2}$ ) therefore stem from (1) the simulated water content based on LM3V-N soil water module, hereafter LM3V-SM (2) the Global Land Data Assimilation System Version 2 with the land surface model NOAH 3.3 (Rodell et al., 2004), hereafter NOAH-SM, and (3) the ERA Interim reanalysis data set from the European Center for Medium range Weather Forecasting (ECMWF; Dee et al., 2011), hereafter ERA-SM. The latter two data sets integrate satellite- and ground-based observations with land surface models. When overriding soil moisture, we linearly interpolated the 3-hourly data onto the 30 min model time step. In these simulations, we allowed soil $\mathrm{C}$ and $\mathrm{N}$ dynamics to vary according to different soil moisture data sets, but kept the model prediction of soil water to use for plant productivity and evapotranspiration.
Parameterization of the soil moisture effect on nitrification and denitrification is based on WFPS. LM3V-N uses the concept of plant available water, where water that is available to plants varies between the wilting point and field capacity. Water content above field capacity leaves the soil immediately (Milly and Shmakin, 2002), and thus WFPS does not attain high values typically observed during denitrification. To explore the effect of WFPS-soil moisture relationship on $\mathrm{N}_{2} \mathrm{O}$ emissions, we calculated WFPS using three methods. Method 1 assumes WFPS is the ratio of available water and the available water capacity in the rooting zone. In Method 2 we assumed WFPS is the ratio of the water-filled porosity and total porosity which is derived from bulk density (BD, in unit $\mathrm{kg} \mathrm{m}^{-3}$ ). BD was obtained from the Harmonized World Soil Database (HWSD) version 1.1 (Wei et al., 2014). The calculation is given by

$\mathrm{WFPS}=\frac{\frac{\theta}{\rho h_{\mathrm{r}}}}{1-\frac{\mathrm{BD}}{\mathrm{PD}}}$

where $\theta\left(\mathrm{kg} \mathrm{m}^{-2}\right)$ is the root zone soil water; $h_{\mathrm{r}}(\mathrm{m})$ is the effective rooting depth of vegetation; $\rho$ is the density of water $\left(1000 \mathrm{~kg} \mathrm{~m}^{-3}\right)$; and PD is the particle density of soil $\left(2650 \mathrm{~kg} \mathrm{~m}^{-3}\right)$. Method 1 generally leads to an overestimation of WFPS because the available water capacity is smaller than total pore space. In contrast, the use of Method 2 with LM3V-SM creates an underestimation since water is not allowed to accumulate beyond field capacity and misses high WFPS to which nitrification and denitrification are sensitive. Meanwhile, for NOAH-SM and ERA-SM data, Methods 2 is more close to the "real" WFPS and is the default method when using these data sets. The third approach, which is also the default method with LM3V-SM that is applied in the global hindcast experiment, the subsequent elevated $\mathrm{CO}_{2}$ and temperature responses experiment, and sensitivity tests with regard to $\mathrm{N}$ cycling, calculates WFPS as the average of the previous two methods.

For each soil moisture data set ( 3 in total, two replacements and one simulated by LM3V-N), we calculated WFPS using three methods mentioned above. We conducted transient simulations with the nine different WFPSs (three data sets $\times$ three methods) starting from the near-equilibrium state obtained in the global hindcast experiment in Sect. 2.2.1. The use of a less realistic method for WFPS for each soil moisture driver (LM3V-SM, NOAH-SM and ERA-SM) offers insights of the sensitivity of $\mathrm{N}_{2} \mathrm{O}$ emissions to soil moisture. The simulation procedure was the same as that in global hindcast ex- 
periment except for the WFPS. ERA-SM is only available starting from 1979, prior to which simulations were conducted with model default soil moisture (LM3V-SM). Results from ERA-SM were analysed starting from 1982, leaving a short period for adjustment.

\subsubsection{Sensitivity to $\mathrm{N}$ cycling processes and parameterization}

$\mathrm{N}_{2} \mathrm{O}$ emission is constrained by ecosystem availability of mineral $\mathrm{N}$, which is linked to different $\mathrm{N}$ cycling processes in addition to nitrification and denitrification processes. To test the sensitivity of modelled $\mathrm{N}_{2} \mathrm{O}$ emission to the larger plantsoil $\mathrm{N}$ cycle, we conducted the following sensitivity analyses, in the form of one at a time perturbation. We replaced the dynamic BNF scheme with empirically reconstructed preindustrial fixation rates (Cleveland et al., 1999; Green et al., 2004), removing the negative feedback between BNF and plant $\mathrm{N}$ availability. We further shut off $\mathrm{N}$ loss pathways through DON leaching and fire volatilization (with ash_fraction $=1$ ). We expect that these three modifications alleviate $\mathrm{N}$ limitation: prescribed BNF may continuously add $\mathrm{N}$ beyond plant $\mathrm{N}$ demand. Further eliminating fire and DOM N losses leave loss pathways that have to pass the available $\mathrm{N}$ pool thereby opening the possibility of increasing gaseous losses. Further, removing these plant-unavailable pathways (Thomas et al., 2015) increases $\mathrm{N}$ retention and opens the possibility of alleviating $\mathrm{N}$ limitation. In addition, we modified key parameters related to general $\mathrm{N}$ cycling and $\mathrm{N}_{2} \mathrm{O}$ emissions one at a time. We multiplied several parameters that directly affect ammonium and nitrate concentration or $\mathrm{N}_{2} \mathrm{O}$ fluxes by $10(\times 10)$ or $0.1(\times 0.1)$, while keeping other parameters as defaults. Those parameters control the active root $\mathrm{N}$ uptake rates $\left(v_{\max }\right)$, nitrification rate $\left(k_{\mathrm{n}}\right)$, denitrification rate $\left(k_{\mathrm{d}}\right.$, $\mathrm{Kc}, \mathrm{Kn}$ ) and the fraction of net nitrification lost as $\mathrm{N}_{2} \mathrm{O}$ (frac).

\subsubsection{Responses to elevated $\mathrm{CO}_{2}$ and temperature}

Responses of $\mathrm{N}_{2} \mathrm{O}$ emissions to atmospheric $\mathrm{CO}_{2}$ and global warming have been reported at field scale (Dijkstra et al., 2012; van Groenigen et al., 2011). Here, we evaluate the model's response to step changes in the form of a doubling of preindustrial $\mathrm{CO}_{2}$ level (284 to $568 \mathrm{ppm}$ ) and a $2 \mathrm{~K}$ increase in atmospheric temperature. Starting from the same quasi-equilibrium state with potential vegetation as in the global hindcast experiment in Sect. 2.2.1, we conducted four transient model runs: (1) the CONTROL run with the same drivers as spin-up; (2) the CO2_FERT run with the same drivers as the CONTROL except a doubling of atmospheric $\mathrm{CO}_{2}$ level; (3) the TEMP run with the same drivers as the CONTROL except a $2 \mathrm{~K}$ rise in atmospheric temperature; and (4) the CO2_FERT $\times$ TEMP run with both the doubling of $\mathrm{CO}_{2}$ and $2 \mathrm{~K}$ rise in temperature. For each experiment, we ran the model for 100 years and evaluated the corresponding results.

\subsection{Comparisons with observations}

We compared our model results for annual $\mathrm{N}_{2} \mathrm{O}$ gas loss with field data. We compiled annual $\mathrm{N}_{2} \mathrm{O}$ emissions from peerreviewed literature (see Appendix A for more information). To increase the representativeness of the measurements, we included only sites with more than 3 months or 100 days experimental span. Only locations with at least 50 years nondisturbance history for forests and 10 years for vegetation other than forests were included. The compiled 61 measurements cover a variety of spatial ranges with vegetation types including tropical rainforest, temperate forest, boreal forest, tundra, savanna, perennial grass, steppe, alpine grass and desert vegetation. Multiple measurements falling into the same model grid cell were averaged. If the authors had indicated the dominant vegetation or soil type, we used the values reported for the dominant type instead of the averaged. For multiyear measurements, even if the authors gave the individual year's data, we averaged the data to avoid overweighting of long-term studies. If the location was between borders of different model grid cells, we averaged across the neighbouring grid cells.

We also compared monthly $\mathrm{N}_{2} \mathrm{O}$ fluxes at a group of sites: (a) the Tapajós National Forest in Amazonia $\left(3^{\circ} \mathrm{S}\right.$, $55^{\circ} \mathrm{W}$ ), taken from Davidson et al. (2008); (b) the Hubbard Brook Experimental Forest in New Hampshire, USA $\left(44^{\circ} \mathrm{N}, 72^{\circ} \mathrm{W}\right)$, as described in Groffman et al. (2006); (c) the cedar forest from Oita, Japan $\left(33^{\circ} \mathrm{N}, 131^{\circ} \mathrm{E}\right)$, as described in Morishita et al. (2007); (d) the Leymus chinensis (LC) and Stipa grandis (SG) steppe in Inner Mongolia, China ( $\left.44^{\circ} \mathrm{N}, 117^{\circ} \mathrm{E}\right)$, taken from Xu-Ri et al. (2003); (e) the cedar forest in Fukushima, Japan $\left(37^{\circ} \mathrm{N}, 140^{\circ} \mathrm{E}\right)$, taken from Morishita et al. (2007); and (f) the primary (P1 and P2) and secondary (L1 and L2) forests located at the Pasir Mayang Research Site $\left(1^{\circ} \mathrm{S}, 102^{\circ} \mathrm{E}\right)$, Indonesia, taken from Ishizuka et al. (2002). In addition, daily measurements of soil temperature, soil moisture and $\mathrm{N}_{2} \mathrm{O}$ emissions were compared at four German forest sites located in the same grid cell $\left(50^{\circ} \mathrm{N}\right.$, $8^{\circ} \mathrm{E}$ ), as described in Schmidt et al. (1988).

\section{Results}

\subsection{Global budget, seasonal and inter-annual variability}

Our modelled global soil $\mathrm{N}_{2} \mathrm{O}$ flux is $6.69 \pm 0.32 \mathrm{TgN} \mathrm{yr}^{-1}$ (1970-2005 mean and standard deviation among different years; Fig. 1) with LM3V-SM (Method 3, default method for LM3V-N calculated soil moisture), $5.61 \pm 0.32 \mathrm{TgN} \mathrm{yr}^{-1}$ with NOAH-SM (Method 2) and $7.47 \pm 0.30 \mathrm{TgN} \mathrm{yr}^{-1}$ with ERA-SM (1982-2005, Method 2) which is within the range of reported values. The central estimate of $\mathrm{N}_{2} \mathrm{O}$ emission from soils under natural vegetation is $6.6 \mathrm{TgN} \mathrm{yr}^{-1}$ based on the Intergovernmental Panel on Climate Change (IPCC) AR5 


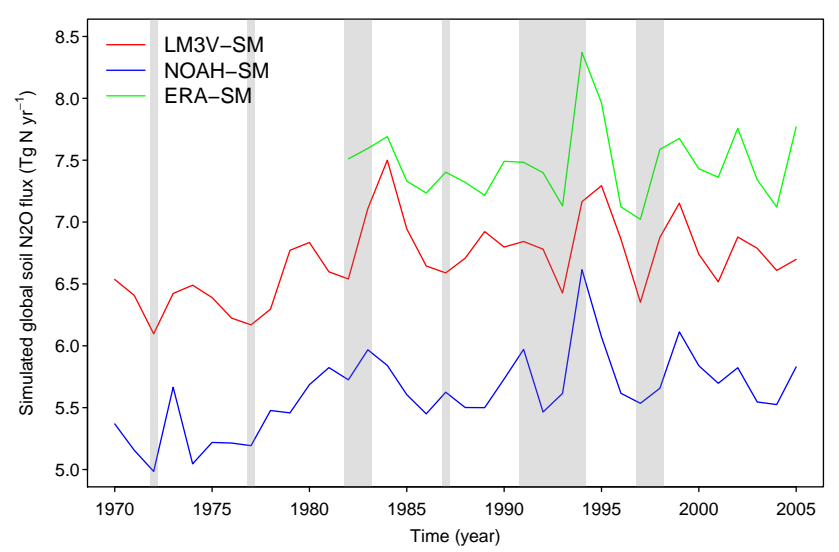

Figure 1. Simulated annual global soil $\mathrm{N}_{2} \mathrm{O}$ emissions based on potential vegetation (1970-2005). Shaded grey area indicates El Niño years with the annual multivariate ENSO index (MEI) greater than 0.6. Colours refer to different soil moisture data set used in the estimation: red for LM3V-SM (with WFPS calculated by Method 3); blue for NOAH-SM (Method 2) and green for ERA-SM (Method 2). Details for these soil moisture data sets and WFPS calculating methods are available in the main text.

(Ciais et al., 2013; range, 3.3-9.0 $\mathrm{TgN} \mathrm{yr}^{-1}$ ) for the mid1990s. Mean estimation for the period of 1975-2000 ranged from 7.4 to $10.6 \mathrm{TgN} \mathrm{yr}^{-1}$ with different precipitation forcing data (Saikawa et al., 2013). Xu-Ri et al. (2012) reported the decadal-average to be $8.3-10.3 \mathrm{TgN} \mathrm{yr}^{-1}$ for the 20th century. Potter and Klooster (1998) reported a global mean emission rate of $9.7 \mathrm{TgN} \mathrm{yr}^{-1}$ over $1983-1988$, which is higher than the earlier version of their model $\left(6.1 \mathrm{TgN} \mathrm{yr}^{-1}\right)$ (Potter et al., 1996). Other estimates include 6-7 $\mathrm{TgN} \mathrm{yr}^{-1}$ (Syakila and Kroeze, 2011), 6.8 $\mathrm{TgN} \mathrm{yr}^{-1}$ based on the OCN model (Zaehle et al., 2011), 3.9-6.5 $\mathrm{TgN} \mathrm{yr}^{-1}$ for preindustrial periods from a top-down inversion study (Hirsch et al., 2006), $1.96-4.56 \mathrm{TgN} \mathrm{yr}^{-1}$ in 2000 extrapolated from field measurements by an artificial neural network approach

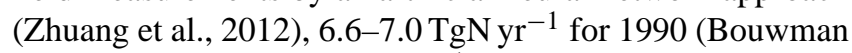
et al., 1995), and 7-16 $\mathrm{TgN} \mathrm{yr}^{-1}$ (Bowden, 1986) as well as $3-25 \mathrm{TgN} \mathrm{yr}^{-1}$ (Banin, 1986) from two earlier studies.

Following Thompson et al. (2014), El Niño years are set to the years with the annual multivariate ENSO index (MEI) greater than 0.6. 1972, 1977, 1982, 1983, 1987, 1991, 1992, 1993, 1994, 1997 and 1998 were chosen as El Niño years. We detected reduced emissions during El Niño years (Fig. 1), in line with the global atmospheric inversion study of Thompson et al. (2014) and the process based modelling study from Saikawa et al. (2013).

Figure 2 shows the simulated global natural soil $\mathrm{N}_{2} \mathrm{O}$ emissions in four seasons averaged over the period of 19702005 based on LM3V-SM (Method 3). The Northern Hemisphere displays a large seasonal variability, with the highest emissions in the northern summer (JJA, June to August) and lowest in winter (DJF, December to February). Globally, northern spring (MAM, March to May) has the highest emis- sion rate $(2.07 \mathrm{TgN})$ followed by summer $(1.89 \mathrm{TgN})$. The lower emissions in summer compared to spring stem from a reduced contribution of the Southern Hemisphere during northern summer.

As expected, a large portion (more than $60 \%$ ) of the soil $\mathrm{N}_{2} \mathrm{O}$ fluxes have tropical origin $\left(23.5^{\circ} \mathrm{S}\right.$ to $\left.23.5^{\circ} \mathrm{N}\right)$, while emissions from cooler regions are limited by temperature and arid/semi-arid regions by soil water. Our modelling results suggest year-round high emission rates from humid zones of Amazonia, east central Africa, and throughout the islands of Southeast Asia, with small seasonal variations (Fig. 2). Emissions from tropical savannah are highly variable, with locations of both high fluxes (seasonal mean $>30 \mathrm{mgN} \mathrm{m}^{-2}$ month $^{-1}$ or $3.6 \mathrm{~kg} \mathrm{ha}^{-1} \mathrm{yr}^{-1}$ ) and low fluxes (seasonal mean $<1.3 \mathrm{mgN} \mathrm{m}^{-2}$ month $^{-1}$ or $\left.0.16 \mathrm{~kg} \mathrm{ha}^{-1} \mathrm{yr}^{-1}\right)$. The simulated average tropical emission rate is $0.78 \mathrm{kgNha}^{-1} \mathrm{yr}^{-1}(1970-2005)$, within the range of estimates $\left(0.2-1.4 \mathrm{kgN} \mathrm{ha}^{-1} \mathrm{yr}^{-1}\right)$ based on sitelevel observations from the database of Stehfest and Bouwman (2006), but smaller than a more detailed simulation study $\left(1.2 \mathrm{kgN} \mathrm{ha}^{-1} \mathrm{yr}^{-1}\right)$ carried out by Werner et al. (2007). Our analysis here excluded land cover, land use changes and human management impacts, while most of the observation-based or regional modelling studies did not factor out those impacts. Our modelling result in natural tropics is comparable with another global modelling study (average emission rate, $0.7 \mathrm{kgN} \mathrm{ha}^{-1} \mathrm{yr}^{-1}$; Zaehle et al., 2010), in which the authors claimed they may underestimate the tropical $\mathrm{N}_{2} \mathrm{O}$ sources compared to the inversion estimates from the atmospheric transport model TM3 (Hirsch et al., 2006).

\subsection{Sensitivity to WFPS}

The different parameterization of WFPS and the use of different soil moisture modelling and data allow to test the sensitivity of soil $\mathrm{N}_{2} \mathrm{O}$ emissions to variable WFPS. Globally, emissions generally increase with WFPS (Fig. 3). WFPS derived from Method 1 is higher than that based on Method 2. Data-derived soil moisture data sets combined with different calculation methods together produced a range of $0.15-0.72$ for the global mean WFPS (1982-2005). While mean values greater than 0.6 (approximately field capacity) are less realistic, these high WFPS values provide the opportunity to test the model's response to the soil moisture-based parameterization of redox conditions in soils. Global soil $\mathrm{N}_{2} \mathrm{O}$ emissions are highly sensitive to WFPS, with approximately $0.25 \mathrm{TgN}$ per year per 0.01 change in global mean WFPS in the range 0 to 0.6 . The spatial and temporal characteristic of WFPS also matters. Emission rate from LM3V-SM (Fig. 3 green circle) is $1.13 \mathrm{TgN} \mathrm{yr}^{-1}$ higher than that from NOAHSM (Fig. 3 blue triangle), while both model configurations have the same mean WFPS (ca. 0.21), highlighting effects of regional and temporal differences between the soil moisture products. 

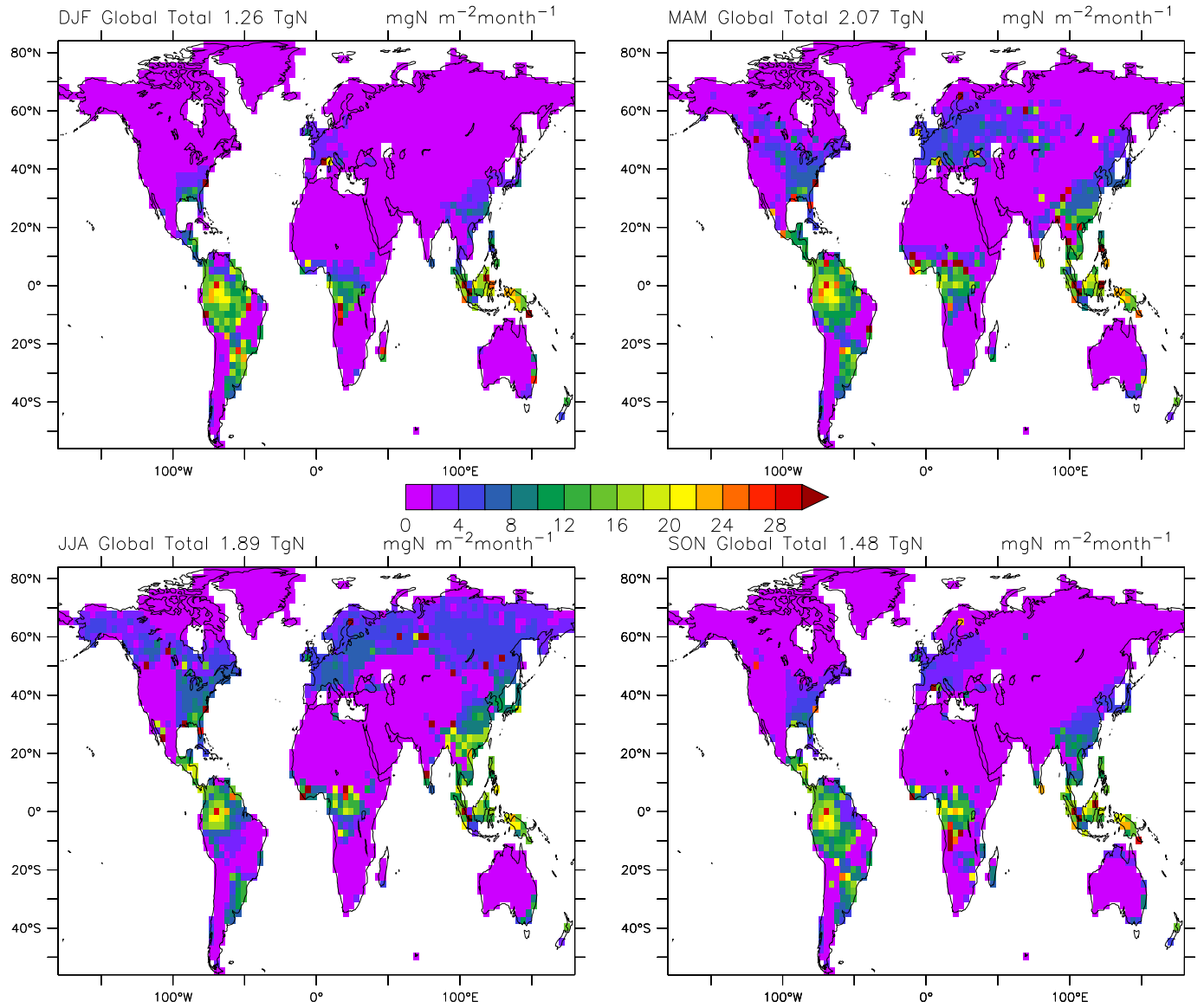

Figure 2. Global seasonal mean soil $\mathrm{N}_{2} \mathrm{O}$ emissions (with potential vegetation) averaged over the years 1970-2005. DJF (December, January and February), stands for Northern Hemisphere winter; MAM (March, April and May) for spring; JJA (June, July and August) for summer; and SON (September, October and November) for autumn.

\subsection{Model-observation comparisons}

Modelled $\mathrm{N}_{2} \mathrm{O}$ emissions capture the average of cross-site observed annual mean emissions (0.54 vs. $0.53 \mathrm{kgN} \mathrm{ha}^{-1} \mathrm{yr}^{-1}$ based on LM3V-SM) reasonably (Appendix A and Fig. 4a), but spread considerably along the $1: 1$ line. The points deviating the most are from tropical forests, with overestimations from montane tropical forest and underestimations from lowland tropical forests if those measurements are representative of gridcell emissions. These patterns are similar as results from NOAH-SM (Appendix A and Fig. 4b) and ERA-SM (Appendix A and Fig. 4c), except that the application of WFPS from NOAH-SM slightly underestimates the observed global mean $\left(0.54\right.$ vs. $0.47 \mathrm{kgN} \mathrm{ha}^{-1} \mathrm{yr}^{-1}$ from NOAH-SM with WFPS based on Method 2).

At the Tapajós National Forest, results from LM3V-SM capture some of the variations in $\mathrm{N}_{2} \mathrm{O}$ fluxes, but the model is not able to reproduce the high emissions observed during spring (Fig. 5a), which might be caused by the underestimation of WFPS in models. We used a total porosity of
0.62 (Davidson et al., 2004) to estimate root zone WFPS based on the reported soil water content (Davidson et al., 2008). The average WFPS from observation is estimated to be 0.49 , which is higher than the modelled average of root zone WFPS for all three model configurations (LM3V-SM 0.27 , NOAH-SM 0.30, and ERA-SM 0.37). WFPS varies between $<0.05$ and 0.45 in LM3V-SM (range from 0.20 to 0.36 in NOAH-SM and 0.30 to 0.41 in ERA-SM), and contrasts with observation that show seasonal variations with WFPS in the range of 0.37 to 0.58. At the Hubbard Brook Experimental Forest, the correlations between model results and observations are 0.51 (LM3V-SM), 0.56 (NOAH-SM) and 0.62 (ERA-SM) for yellow birch, 0.66 (LM3V-SM), 0.68 (NOAH-SM) and 0.70 (ERA-SM) for sugar maple. However, the model is less robust in reproducing the magnitude of emission peaks. Groffman et al. (2006) suggested high emissions of $\mathrm{N}_{2} \mathrm{O}$ in winter were associated with soil freezing. However, the model assumes little emissions when soil temperature is under $0^{\circ} \mathrm{C}$. In addition, observations suggested $\mathrm{N}_{2} \mathrm{O}$ uptake (negative values in Fig. 5b) while the model does not incorporate mechanisms to represent $\mathrm{N}_{2} \mathrm{O}$ uptake. At 


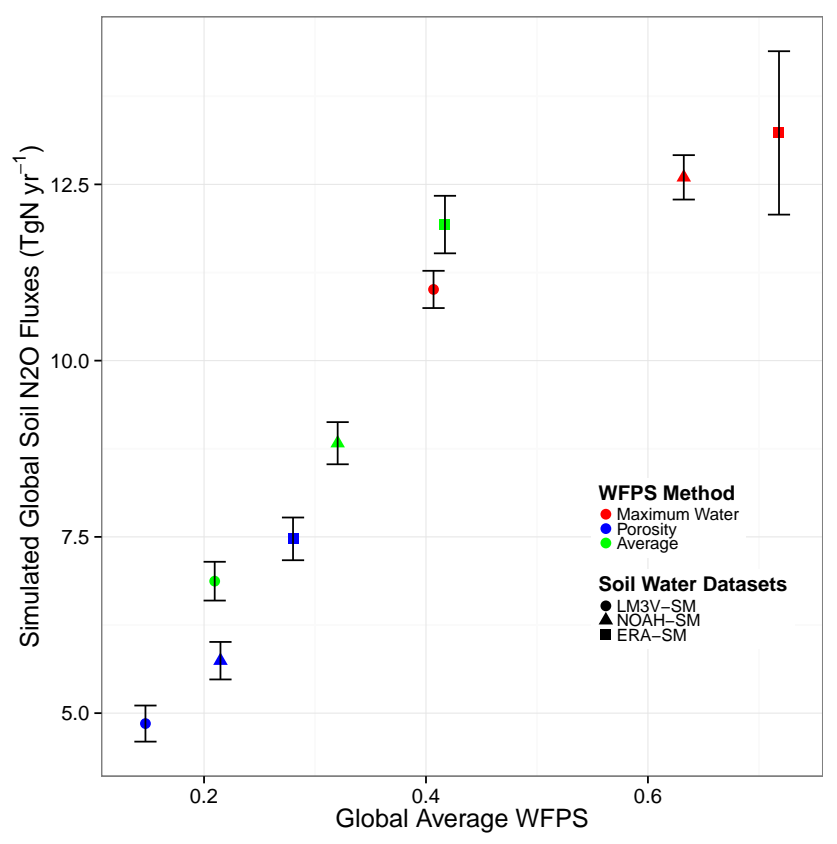

Figure 3. Sensitivity of simulated global soil $\mathrm{N}_{2} \mathrm{O}$ emissions (with potential vegetation) to water-filled pore space (WFPS). The $x$ axis is the WFPS averaged globally over 1982-2005; the $y$ axis represents the corresponding global total $\mathrm{N}_{2} \mathrm{O}$ fluxes. A total of nine sets of WFPS are obtained through either different soil water data sets (symbols) or varied calculation methods (colours). Maximum water, porosity and average correspond to method 1 , method 2 and method 3 in the main text, respectively. Coloured symbols represent means and error bars indicate interannual standard deviations.

the Oita cedar forest, LM3V-N reproduces the seasonality of $\mathrm{N}_{2} \mathrm{O}$ emissions accurately (Fig. 5c). ERA-SM overestimates the magnitude of $\mathrm{N}_{2} \mathrm{O}$ fluxes from Inner Mongolia grassland, while the magnitudes produced from LM3V-SM and NOAHSM are comparable with observations. However, the timing of the emission peaks are 1 or 2 months in advance in the model compared to observations (Fig. 5d). WFPS at a nearby meteorological station fluctuated between 0 and 0.5 for $0-$ $20 \mathrm{~cm}$ depth (Xu-Ri et al., 2003) which agrees with our values based on LM3V-SM and ERA-SM, but the range is lower for NOAH-SM (0.05 to 0.35). At the specific plots, Xu-Ri et al. (2003) reported a mean WFPS of 0.32 in one plot (LC) and 0.20 in the other plot (SG) for the 0 to $0.1 \mathrm{~m}$ depth interval which are close to ERA-SM and NOAH-SM (LM3V-SM 0.14, NOAH-SM 0.19, ERA-SM 0.30), however, no temporal information was provided for the specific sites. At the Fukushima cedar forest, similar as at the Oita cedar forest, models are less robust at capturing the magnitude of high peaks of $\mathrm{N}_{2} \mathrm{O}$ emissions although the seasonality produced by the model are good (Fig. 5e). Emissions in the primary and secondary tropical rainforest at the Pasir Mayang Research Site are highly variable, which makes the comparison difficult (Fig. 5f). LM3 V-SM (but not ERA-SM and NOAH$\mathrm{SM})$ reproduces the low emissions in September-November
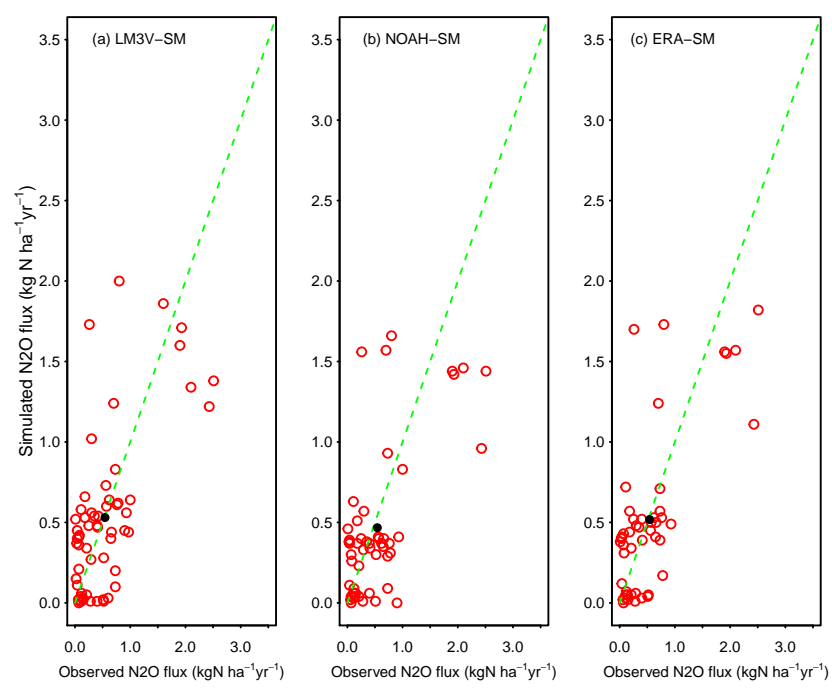

Figure 4. Observed vs. simulated annual $\mathrm{N}_{2} \mathrm{O}$ emissions from natural soils. Dashed green lines are the $1: 1$ lines. The solid circles represent the overall means. Different panels represent simulations with different soil moisture data: (a) LM3V-SM (simulated by LM3V-N); (b) NOAH-SM (based on land surface model NOAH 3.3 in Global Land Data Assimilation System Version 2); and (c) ERA-SM (reanalysis data from ECMWF). Water-filled pore space (WFPS) is calculated using the average of the one based on available water capacity and the one based on the total porosity (Method 3, see the main text for detailed description) for panel (a); and using the total porosity (Method 2) for panel (b) and (c).

1997 and the increase of emissions from secondary forests in December, 1997. Overall, modelled variability is smaller compared to observation across these sites.

The strong variability of measured $\mathrm{N}_{2} \mathrm{O}$ emissions is further illustrated in Fig. 6. Differences in measured $\mathrm{N}_{2} \mathrm{O}$ fluxes between different forest sites are large, reflecting heterogeneity that is not captured within one model grid cell. In addition, the error bars, which represent the standard deviation of measured $\mathrm{N}_{2} \mathrm{O}$ fluxes at three different plots of the same forest, are large. The standard deviation is as high as $49.27 \mu \mathrm{gN} \mathrm{m}^{-2} \mathrm{~h}^{-1}$, indicating the strong variability of measured $\mathrm{N}_{2} \mathrm{O}$ fluxes at the plot scale. Modelled $\mathrm{N}_{2} \mathrm{O}$ fluxes are generally within the range of measured $\mathrm{N}_{2} \mathrm{O}$ emissions. Model outputs slightly underestimate $\mathrm{N}_{2} \mathrm{O}$ emissions partly due to the underestimation of soil water content (Fig. 6b).

\subsection{Sensitivity to $\mathbf{N}$ cycling processes and parameterization}

Disallowing $\mathrm{N}$ losses through DON and fire volatilization enhance ecosystem $\mathrm{N}$ accumulation and availability to plants and microbes, and therefore increases $\mathrm{N}_{2} \mathrm{O}$ emissions (Fig. 7a). The gain in $\mathrm{N}_{2} \mathrm{O}$ emissions from disallowing DON loss is small $\left(0.12 \mathrm{TgN} \mathrm{yr}^{-1}\right)$. However, $\mathrm{N}_{2} \mathrm{O}$ emission is on average (1950-2005) increased by $3.63 \mathrm{TgN} \mathrm{yr}^{-1}$ in the absence of fire volatilization $\mathrm{N}$ loss (we note that fires do occur, 
but $\mathrm{N}$ is retained as ash in the litter). The gain is most evident in tropical regions (not shown), indicating the importance of fire in regulating ecosystem $\mathrm{N}$ status. Simulated preindustrial $\mathrm{BNF}$ is smaller than the empirical reconstructed BNF (72 in LM3V-N vs. $108 \mathrm{TgN} \mathrm{yr}^{-1}$ from empirical based data, Green et al., 2004). However, BNF in LM3V-N increases with time under historical varying climate, increasing atmospheric $\mathrm{CO}_{2}$ level and $\mathrm{N}$ deposition. The global average BNF simulated for the period 1950-2005 is $100 \mathrm{TgN} \mathrm{yr}^{-1}$, close to the empirical value. Nevertheless, substitution of BNF in LM3V$\mathrm{N}$ by empirical preindustrial value increased $\mathrm{N}_{2} \mathrm{O}$ flux by 1.2 $\mathrm{TgN} \mathrm{yr}^{-1}$ (Fig. 7a).

Among the specific parameters tested, $\mathrm{N}_{2} \mathrm{O}$ emission is most sensitive to the 10 times change $(\times 10)$ of the fraction of net nitrification lost as $\mathrm{N}_{2} \mathrm{O}$ gas. The relative magnitude of $\mathrm{N}_{2} \mathrm{O}$ flux on average (1950-2005) reaches 6.5 times the default (Fig. 7b). Reduction $(\times 0.1)$ of maximum active plant $\mathrm{N}$ uptake strength $\left(v_{\max }\right)$ strongly increases $\mathrm{N}_{2} \mathrm{O}$ emissions (ca. by 3 times the default). Meanwhile, enhancement of $v_{\max }$ also increases $\mathrm{N}_{2} \mathrm{O}$ fluxes, reflecting the non-linear response of $\mathrm{N}_{2} \mathrm{O}$ emissions to $v_{\max } \cdot \times 10 k_{\mathrm{n}}$, the maximum nitrification rate and denitrification rate $k_{\mathrm{d}}$ increase $\mathrm{N}_{2} \mathrm{O}$ emissions, while $\times 0.1$ decrease $\mathrm{N}_{2} \mathrm{O}$ flux. $\mathrm{N}_{2} \mathrm{O}$ increases more with increasing $k_{\mathrm{d}}$ than with increasing $k_{\mathrm{n}}$, whereas reduction of $k_{\mathrm{n}}$ $(\times 0.1)$ produces a stronger response than reduction of $k_{\mathrm{d}}$. The half-saturation constant that represents the regulation of labile carbon availability on denitrification rate, $\mathrm{Kc}$, is the least sensitive parameter. Meanwhile, reduction $(\times 0.1)$ of the half-saturation constant $\mathrm{Kn}$ that represents the regulation of substrate availability on denitrification rate on average increased $\mathrm{N}_{2} \mathrm{O}$ fluxes by $4.5 \mathrm{TgN} \mathrm{yr}^{-1}$ (Fig. 7b).

\section{5 $\mathrm{CO}_{2}$ and temperature responses}

Globally, $\mathrm{N}_{2} \mathrm{O}$ emissions respond to a step $\mathrm{CO}_{2}$ increase first with a decline to ultimately increased levels after approximately 40 years (Fig. 8a, black line). The simulated global response follows largely the behaviour as simulated for tropical forests (Fig. 8a, yellow line). The shift from a negative to a positive response indicates possible competing mechanisms operating on different timescales. Field level experiments revealed the highly variable effects of $\mathrm{CO}_{2}$ fertilization on $\mathrm{N}_{2} \mathrm{O}$ emissions. Based on a meta-analysis, van Groenigen et al. (2011) suggested that elevated $\mathrm{CO}_{2}$ significantly increased $\mathrm{N}_{2} \mathrm{O}$ emission by $18.8 \%$, while Dijkstra et al. (2012) argued for a non-significant response in non$\mathrm{N}$-fertilized studies. In contrast to observation studies, the global C-N cycle model analyses from O-CN suggested negative $\mathrm{CO}_{2}$ fertilization effects on $\mathrm{N}_{2} \mathrm{O}$ emissions (Zaehle et al., 2011). The negative impacts (reduced $\mathrm{N}_{2} \mathrm{O}$ flux), which are also reported in manipulative experiments, are likely from increased plant $\mathrm{N}$ and immobilization demand under $\mathrm{CO}_{2}$ fertilization, reducing $\mathrm{N}$ availability for nitrifiers and denitrifiers (Dijkstra et al., 2012). $\mathrm{CO}_{2}$ fertilization on average (over 100 years) increased the global mean plant nitro- gen uptake rate by $10.02 \mathrm{kgN} \mathrm{ha}^{-1} \mathrm{yr}^{-1}$, as shown in Fig. $9 \mathrm{~b}$. Modelled soil inorganic $\mathrm{N}$ content (ammonium and nitrate) is reduced at first, but the reduction is not sustained. One mechanism to alleviate $\mathrm{CO}_{2}$ fertilization induced $\mathrm{N}$ limitation is through BNF, which is on average (over 100 years) more than doubled (Fig. 9e). Similar to manipulative field experiments (Dijkstra et al., 2012), positive effects (increase $\mathrm{N}_{2} \mathrm{O}$ fluxes) can result from the impacts of elevated $\mathrm{CO}_{2}$ level to increase litter production (Fig. 9a) and consequently $\mathrm{C}$ sources for denitrifiers, and to increase soil moisture (Fig. 9d) from reduced stomatal conductance and leaf transpiration (Fig. 9c).With both positive and negative mechanisms embedded in our model, the net effects depend on the relative strength of these opposing forces.

Temperate deciduous forests, where most of the forest $\mathrm{CO}_{2}$ fertilization experiments are conducted, respond positively to elevated $\mathrm{CO}_{2}$ levels (Fig. 8a, green line). The slight increase in modelled $\mathrm{N}_{2} \mathrm{O}$ emission is comparable with the mean response of field data compiled for temperate forests (ca. $0.01-0.03 \mathrm{kgN} \mathrm{yr}^{-1} \mathrm{ha}^{-1}$; Dijkstra et al., 2012). A similar positive response was detected for cold evergreen forests (Fig. 8a, pink line) with stronger magnitude compared to temperate deciduous forests. For grasslands, Dijkstra et al. (2012) reported small negative mean response from northern mixed prairie $\left(\Delta \mathrm{N}_{2} \mathrm{O}\right.$, ca. -0.01 to $-0.03 \mathrm{kgN} \mathrm{yr}^{-1} \mathrm{ha}^{-1}$ ), zero mean response from shortgrass steppe and positive mean response from annual grassland (ca. $0.03-0.06 \mathrm{kgN} \mathrm{yr}^{-1} \mathrm{ha}^{-1}$ ). Our model shows a small negative mean response from $\mathrm{C} 4$ grassland (Fig. 8a, cyan line) with the similar magnitude of that reported for the Northern mixed prairie, where the composition of $\mathrm{C} 4$ grass varies (Dijkstra et al., 2012). A $\mathrm{CO}_{2}$ increase in $\mathrm{C} 3$ grassland initially reduces $\mathrm{N}_{2} \mathrm{O}$ emission (Fig. 8a, blue line). However, this slight negative response turns into a small positive within 1 decade.

Elevated temperature generally increases $\mathrm{N}_{2} \mathrm{O}$ emissions except for the slight negative effect in $\mathrm{C} 4$ grass (Fig. 8b). Overall the response to a 2 degree warming is bigger than that of doubling of $\mathrm{CO}_{2}$. The simulated temperature effects are more pronounced in the first decade and decrease over time in tropical forests (Fig. 8b, yellow line), while for the temperate deciduous forests (Fig. 8b, green line) and boreal forests (Fig. 8b pink line), the temperature effects become more pronounced over time. Simulated temperate forest response (in the first decade) is close to that of observed mean (ca. 0.2$0.5 \mathrm{kgN} \mathrm{yr}^{-1} \mathrm{ha}^{-1}$; Dijkstra et al., 2012). Our modelled slight negative response in $\mathrm{C} 4$ grass and positive in $\mathrm{C} 3$ grass are in alignment with data compiled by Dijkstra et al. (2012) who reported both positive and negative responses in grasslands.

The results of combining $\mathrm{CO}_{2}$ and temperature are similar to the $\mathrm{CO}_{2}$ effect alone (Fig. 8c), despite the fact that the individual effect of temperature is much stronger than that of $\mathrm{CO}_{2}$. This antagonistic interaction (i.e. the combined enhancement in $\mathrm{N}_{2} \mathrm{O}$ flux from elevated $\mathrm{CO}_{2}$ and temperature are smaller than the summary of their individual effects) is 

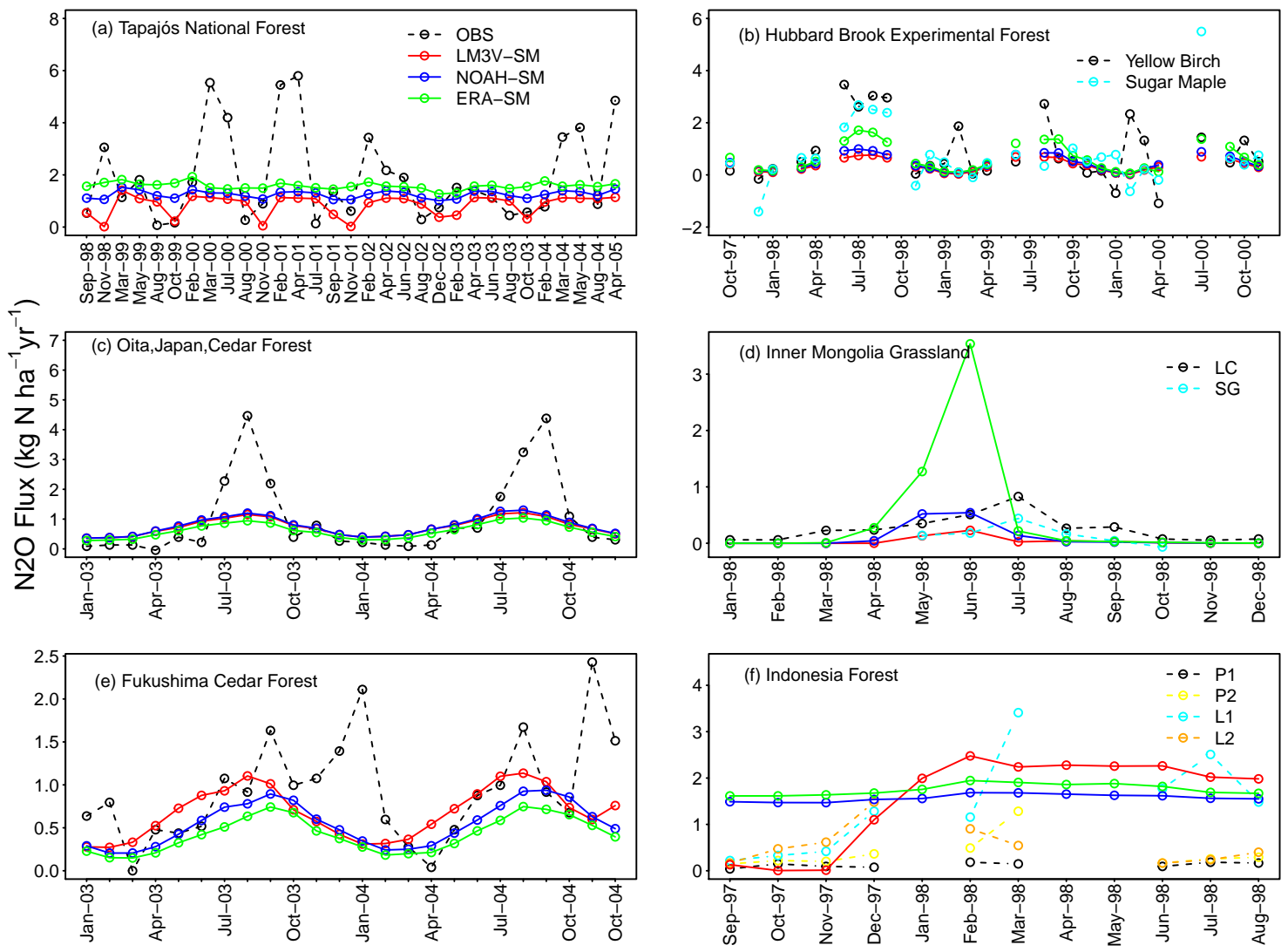

Figure 5. Observed vs. simulated monthly $\mathrm{N}_{2} \mathrm{O}$ emissions at (a), the Tapajós National Forest in east-central Amazonia $\left(3^{\circ} \mathrm{S}, 55^{\circ} \mathrm{W}\right)$, taken from Davidson et al. (2008); (b) the Hubbard Brook Experimental Forest in New Hampshire, USA (44 $\left.{ }^{\circ} \mathrm{N}, 72^{\circ} \mathrm{W}\right)$, taken from Groffman et al. (2006); (c) a cedar forest at Oita, Japan $\left(33^{\circ} \mathrm{N}, 131^{\circ} \mathrm{E}\right)$, taken from Morishita et al. (2007); (d) the Leymus chinensis (LC) and Stipa grandis (SG) steppe in Inner Mongolia, China ( $\left.44^{\circ} \mathrm{N}, 117^{\circ} \mathrm{E}\right)$, taken from Xu-Ri et al. (2003); (e) a cedar forest in Fukushima, Japan (37 $\mathrm{N}$, $140^{\circ} \mathrm{E}$ ), taken from Morishita et al. (2007); and (f) the primary (P1 and P2) and secondary (L1 and L2) forests located at the Pasir Mayang Research Site, Indonesia, taken from Ishizuka et al. $\left(2002 ; 1^{\circ} \mathrm{S}, 102^{\circ} \mathrm{E}\right)$. Shown are modelled results from three WFPS schemes (LM3V-SM, NOAH-SM and ERA-SM) the same as in Fig. 4.

also evident for $\mathrm{C} 3$ grass (first 50 years), temperate deciduous tree and cold evergreen forests (Fig. 8d).

\section{Discussion}

Our model combines two of the most widely applied biogeochemical models (DNDC and CENTURY) with current advancements in field level studies. The model was capable of reproducing the global mean natural $\mathrm{N}_{2} \mathrm{O}$ emissions in other modelling and inverse methods, and the average of observed cross-site annual mean behaviour. By focusing on the role of soil moisture in $\mathrm{N}_{2} \mathrm{O}$ emissions, we found on a global scale a high dependence of simulated $\mathrm{N}_{2} \mathrm{O}$ emissions on soil moisture (WFPS), mainly driven by emissions from tropical regions. The model broadly reproduced the magnitude and direction of responses to elevated $\mathrm{CO}_{2}$ and temperature from manipulative field experiments where data are available. Both the global total emission as well as the global response to temperature and $\mathrm{CO}_{2}$ increase followed largely by the response of tropical forests, where field experiments are rare and no evaluation of $\mathrm{CO}_{2}$ responses exist.

Soil moisture is a key variable in climate system but difficult to derive or measure at the global scale (Seneviratne et al., 2010). Our modelled fluxes were highly sensitive to WFPS, which is in agreement with observation and model synthesis studies (Heinen, 2006; Butterbach-Bahl et al., 2013). Calculating WFPS from different methods resulted in a difference of more than $5 \mathrm{TgN} \mathrm{yr}^{-1}$ in global soil $\mathrm{N}_{2} \mathrm{O}$ fluxes. Saikawa et al. (2013) found a gap up to $3.5 \mathrm{TgN} \mathrm{yr}^{-1}$ induced by different precipitation forcing data from CLMCN-N2O. It is difficult to single out the difference caused by soil moisture alone from their results. Nevertheless, our previous results highlight the importance of improving the dynamics of soil water and representation of WFPS for the purpose of predicting soil $\mathrm{N}_{2} \mathrm{O}$ emission and climate feedbacks. 


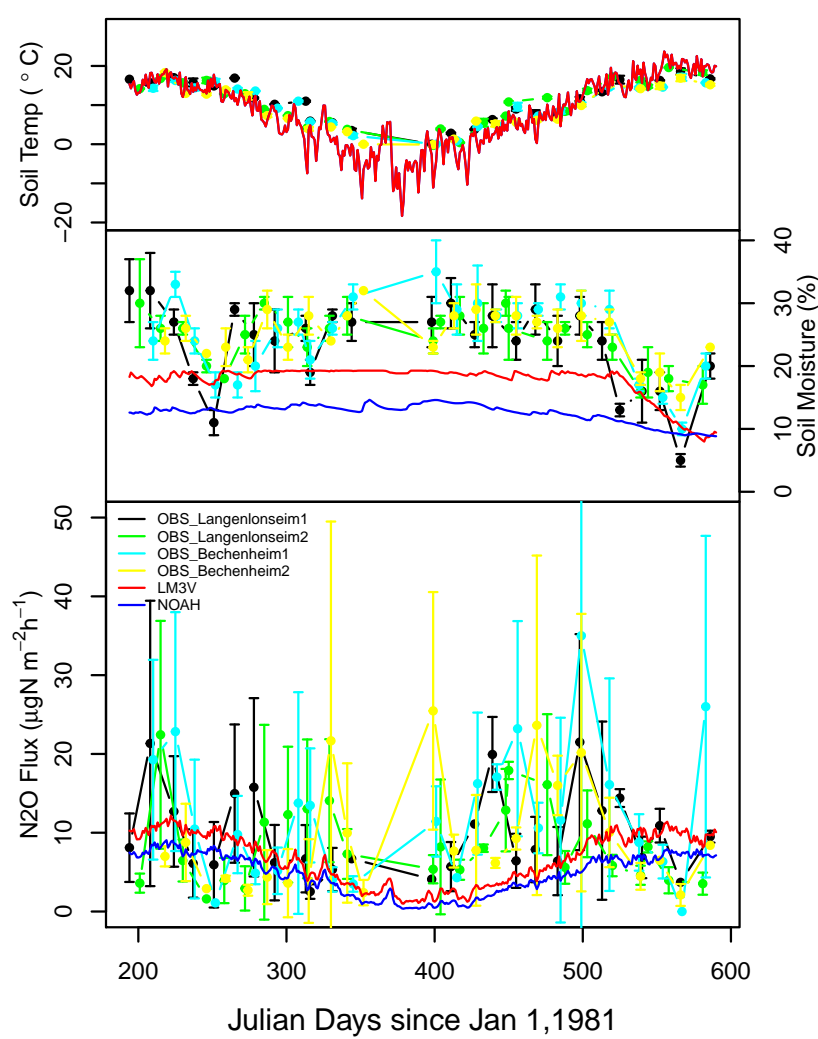

Figure 6. Comparison of (a) soil temperature $(2 \mathrm{~cm}$ from observation and $1 \mathrm{~cm}$ from model) in ${ }^{\circ} \mathrm{C}$; (b) soil moisture $(2 \mathrm{~cm}$ from observation and root zone from model) in $\%$ and (c) soil $\mathrm{N}_{2} \mathrm{O}$ emissions in $\mu \mathrm{gN} \mathrm{m}^{-2} \mathrm{~h}^{-1}$ from observations and model outputs at four forest sites from Germany $\left(50^{\circ} \mathrm{N}, 8^{\circ} \mathrm{E}\right)$, taken from Schmidt et al. (1988). Shown are modelled results from two WFPS schemes (LM3V-SM and NOAH-SM) similar as in Fig. 4.

The root zone soil water in LM3V-N is based on a single layer bucket model. This simplified treatment of soil water dynamics may increase the difficulty in reproducing the temporal and spatial dynamics of WFPS. As a first step, we used the average between the original analog in LM3V-N and a formulation that was derived from soil total porosity to account for actual soil moisture and the possibility of soil water above field capacity. Meanwhile, overriding soil moisture with data-derived products (NOAH-SM and ERA-SM) suggests that the most realistic average (1970-2005) soil $\mathrm{N}_{2} \mathrm{O}$ emission is in the range of $5.61-7.47 \mathrm{TgN} \mathrm{yr}^{-1}$. However, despite using data-derived soil moisture, it appears that the prediction of soil moisture is an impediment towards validating $\mathrm{N}_{2} \mathrm{O}$ emissions at field scale for both LM3V-N simulated and reanalysed soil moisture. If evaluated against field data, the model was capable of representing the mean across sites and to a certain degree also compared adequately with sitespecific time series. However, across the models there are differences between model and data (Fig. 4) particularly peak emissions were poorly represented in the model (Fig. 5), and they can at least partly be attributed to mismatches in

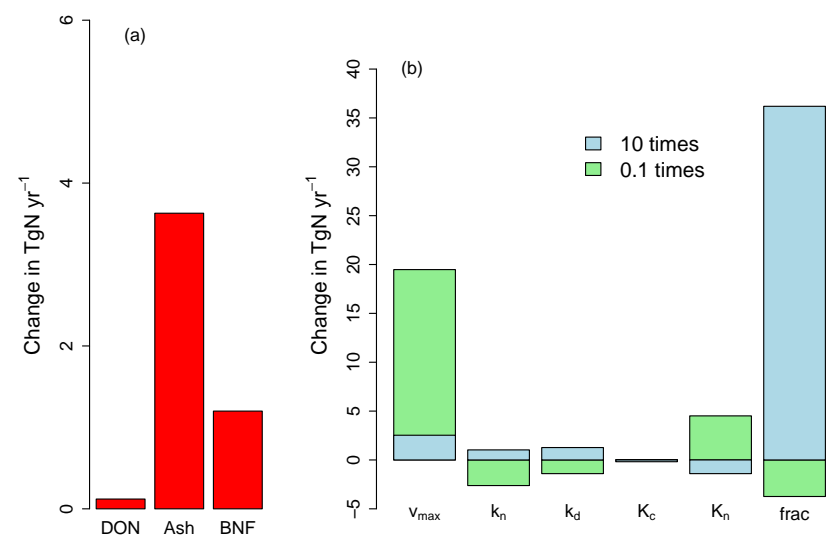

Figure 7. Changes in simulated global average $\mathrm{N}_{2} \mathrm{O}$ (1950-2005) emissions from modifying general $\mathrm{N}$ cycling processes (a) and model parameters one at a time (b). Altered processes include disallowing $\mathrm{N}$ losses through dissolved organic matter (DON in a) and fire volatilization (Ash in a), and replacing simulated biological $\mathrm{N}$ fixation with preindustrial $\mathrm{N}$ fixation rate (BNF in a). Parameters include: $v_{\max }$, the maximum active $\mathrm{N}$ uptake rate per unit root biomass; $k_{\mathrm{n}}$, the base nitrification rate; $k_{\mathrm{d}}$, the base denitrification rate; $\mathrm{Kc}$ and $\mathrm{Kn}$, the half saturation constants for labile $\mathrm{C}$ availability and nitrate respectively; and frac is the fraction of net nitrification lost as $\mathrm{N}_{2} \mathrm{O}$. Parameters are either increased by multiplying 10 (light blue) or reduced by multiplying 0.1 (light green) relative to the defaults.

WFPS. Overall, comparison against field data revealed that the model's variability is smaller compared to observation for both across field sites (Fig. 4) and at different sites (Figs. 5 and 6). One of the reasons for this shortcoming may be that fast transitions, such as freeze-thaw cycle (Groffman et al., 2006) and pulsing (Yienger and Levy, 1995) are not sufficiently captured.

Perhaps equally important to address in future analysis is the tremendous variability of $\mathrm{N}_{2} \mathrm{O}$ emissions from site to site within the same region (see Fig. 6). This field-scale variability highlights the complexity of microscale interactions for $\mathrm{N}_{2} \mathrm{O}$ production, which creates notorious large spatial and temporal variabilities and are undoubtedly difficult to constrain even at the stand level (Butterbach-Bahl et al., 2013). The homogeneous representation of environmental drivers within model grid cells casts doubt on site-specific modelobservation comparison in global simulations. For example, $\mathrm{N}_{2} \mathrm{O}$ emissions vary with topography which are not treated explicitly in most of the global C-N models. 3.8 times difference was detected in a montane forest (Central Sulawesi, Indonesia) moving from 1190 to $1800 \mathrm{~m}$ (Purbopuspito et al., 2006), and 4.3 times difference was found from a tropical moist forest (Brazilian Atlantic Forest) with the altitude changing from 100 to $1000 \mathrm{~m}$ (Sousa Neto et al., 2011).

Globally, $\mathrm{N}_{2} \mathrm{O}$ emissions from nitrification-denitrification were similar to O-CN and LPJ-DyN as they are all derived from DNDC's formulation (Xu-Ri et al., 2012; Zaehle et al., 

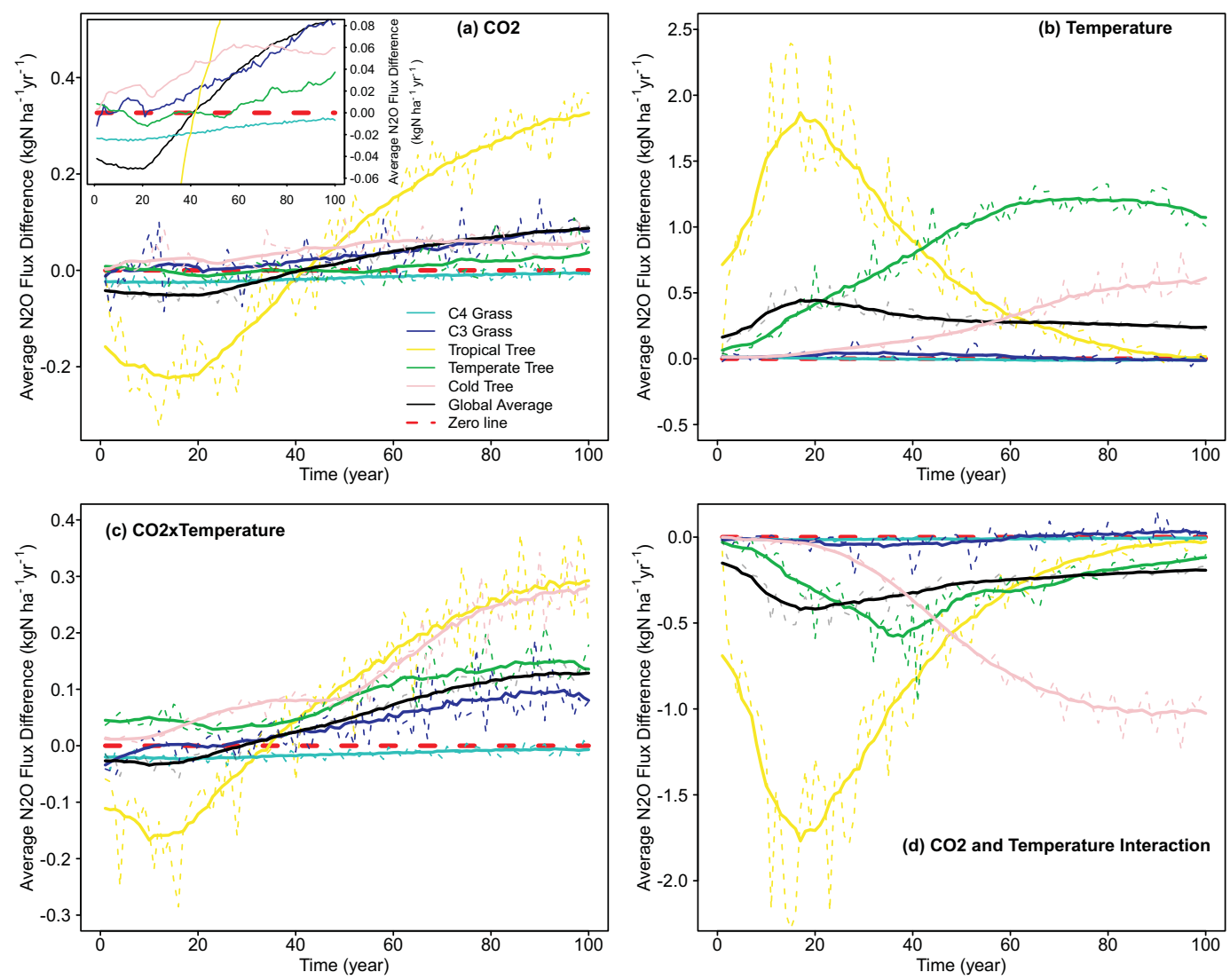

Figure 8. Soil $\mathrm{N}_{2} \mathrm{O}$ emissions in response to step increases in atmospheric $\mathrm{CO}_{2}$ and temperature. Panel (a) is the response to $\mathrm{CO}_{2}$ fertilization alone, expressed as the difference between $\mathrm{CO}_{2}$ increased run and the control run (CO2_FERT - CONTROL), the inset zooms into the $y$ axis (flux difference) around zero; panel (b) is the response to temperature increase alone (TEMP-CONTROL); panel (c) is the combined response to both $\mathrm{CO}_{2}$ enrichment and temperature rise (CO2_FERT $\times$ TEMP-CONTROL); and panel (d) is the interactive effect of $\mathrm{CO}_{2}$ and temperature responses, which is the difference between the combined (results from Panel c) and minus the individual responses (results from Panel $\mathbf{a}$ and $\mathbf{b}$ ). Results are shown as annual values (thin dashed lines) and as running average with a moving window of 17 years (period of recycled climate forcing, thick solid lines). The black lines represent the global average response. Coloured lines indicate responses for biome as represented by each plant functional type (PFT) considered in LM3V-N: C4 grass (cyan), C3 grass (blue), tropical forest (yellow), temperate deciduous forest (green) and cold evergreen forest (pink). Dashed red line represents the zero line.

2011). Embedding an established $\mathrm{N}_{2} \mathrm{O}$ emission module into LM3V-N enables evaluation of the response of $\mathrm{N}_{2} \mathrm{O}$ emissions under different assumptions across models with respect to the dynamics of the larger plant-soil N cycle. Generally, higher inputs from BNF or restriction of losses through organic $\mathrm{N}$ (fire, DON) enhance $\mathrm{N}_{2} \mathrm{O}$ emissions. The representation of BNF in models requires improvement: currently, simple empirical relationships are used, yet BNF is the largest source of new $\mathrm{N}$ in terrestrial systems, and therefore is critical in the determination of $\mathrm{N}$ availability to nitrifiers and denitrifiers. Here we showed that different implementations of $\mathrm{BNF}$ (prescribed vs. responsive to plant $\mathrm{N}$ demand) are globally important for $\mathrm{N}_{2} \mathrm{O}$ emissions. Similarly, the magnitude of $\mathrm{N}$ lost through fire impacted $\mathrm{N}_{2} \mathrm{O}$ emissions in fire prone regions, while $\mathrm{N}$ emission factors are poorly constrained globally (Andreae and Merlet, 2001). The strength of plant uptake of $\mathrm{N}$ posed a strong constraint on the availability of $\mathrm{N}$ for nitrification-denitrification losses as it can draw down $\mathrm{N}$ substantially (Gerber and Brookshire, 2014). A reduction of plant uptake strength allows for relatively more $\mathrm{N}$ allocated for denitrification. More surprising was the positive effect of a stronger plant uptake capacity on $\mathrm{N}_{2} \mathrm{O}$ emissions: enhanced plant uptake allows increased vegetation production and $\mathrm{N}$ throughput through litterfall and mineralization in the long run, which ultimately may allow higher $\mathrm{N}_{2} \mathrm{O}$ losses.

In addition to those $\mathrm{N}$ cycling processes, $\mathrm{N}_{2} \mathrm{O}$ emissions were highly sensitive to the fraction of $\mathrm{N}$ lost as $\mathrm{N}_{2} \mathrm{O}$ during net nitrification. The fraction of $\mathrm{N}_{2} \mathrm{O}$ lost during net nitrification is uncertain. Goodroad and Keeney (1984) suggested a value of $0.1-0.2 \%$, while Khalil et al. (2004) reported a range of $0.16-1.48 \%$ depending on the $\mathrm{O}_{2}$ concentration. We applied a global constant of $0.4 \%$ in our default simulation, bearing in mind the large uncertainties associated with this parameter. 

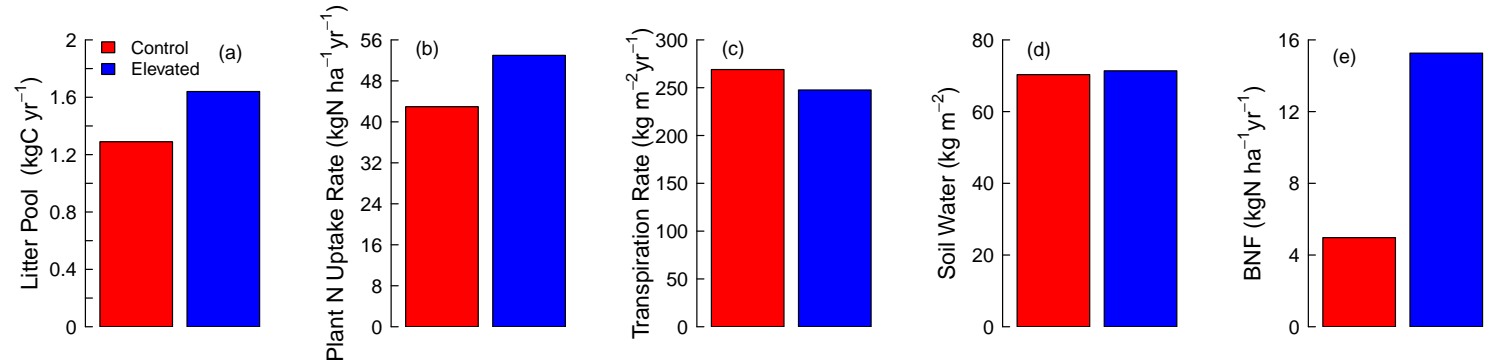

Figure 9. $\mathrm{CO}_{2}$ fertilization effects (no temperature change) on litter pool size (Panel a), plant nitrogen uptake rate (Panel b), canopy transpiration rate (Panel c), soil water content in the root zone (Panel d) and biological nitrogen fixation (BNF) rate (Panel e). Shown is the 100-year average of global means (spatial) for control (284 ppm, red) and with elevated $\mathrm{CO}_{2}$ (568 ppm, blue).

Our results showed that tropical forests play a major role in both rates of emission and responses to perturbations. Tropical forests contributed more than $60 \%$ to the global soil $\mathrm{N}_{2} \mathrm{O}$ fluxes. El Niño events triggered reduced soil $\mathrm{N}_{2} \mathrm{O}$ emissions that are in our simulations similar to earlier estimates (Saikawa et al., 2013; Thompson et al., 2014). El Niño events are known to have induced several of the most wellknown large-scale droughts and altered soil moisture dynamics (Schwalm et al., 2011) in the tropics. Tropical forest $\mathrm{N}_{2} \mathrm{O}$ emissions were highly correlated with root zone soil water content and contributed strongly to the global-scale fluxes of $\mathrm{N}_{2} \mathrm{O}$ in our model. Similarly, global responses to elevated $\mathrm{CO}_{2}$ and temperature were dominated by the tropical response. In contrast to temperate and boreal forests, tropical forests responded negatively to elevated $\mathrm{CO}_{2}$ in the first few decades. The initial negative response of $\mathrm{N}_{2} \mathrm{O}$ emissions to $\mathrm{CO}_{2}$ fertilization in tropical forests produced by LM3V-N stemmed largely from increased demand and uptake of mineral $\mathrm{N}$ due to enhanced vegetation growth under elevated atmospheric $\mathrm{CO}_{2}$ level. Consequently, less $\mathrm{N}$ is available for gaseous losses as the $\mathrm{N}$ cycle tightens. If gross mineralization is used as an indicator of the rate of $\mathrm{N}$ flow in the "holein-the-pipe" concept and gaseous losses are proportional to mineralization, the initial negative response is unlikely to be detected. We found increased mineralization rate with increased litterfall under elevated $\mathrm{CO}_{2}$, while $\mathrm{N}$ availability is reduced from LM3V-N. The mineralization-based approach is likely to predict an increase of losses regardless of $\mathrm{N}$ limitation.

The marked decrease in our simulation for the tropical forests also contrasts somewhat with findings from manipulative field experiments where $\mathrm{CO}_{2}$ enrichment caused decrease, no change or increase across extratropical ecosystems (Dijkstra et al., 2012; van Groenigen et al., 2011), whereas no empirical evidence is available in tropical forests. Overall, the marked differences between tropics and extratropics in response to environmental forcing, and the large contribution of tropical forests to global $\mathrm{N}_{2} \mathrm{O}$ emissions suggest caution when extrapolating field studies mostly carried out in extratropical regions to the globe.
Based on single factor analysis with LM3V-N, the initial response of $\mathrm{N}_{2} \mathrm{O}$ emission to a temperature increase was much larger than the response to increased atmospheric $\mathrm{CO}_{2}$ (Fig. 8). However, we found large interactions between warming and $\mathrm{CO}_{2}$ fertilization, in that the combined effect much more resembled the $\mathrm{CO}_{2}$ effect alone. This interaction is the result of two antagonistic responses where a warming lead to increased $\mathrm{N}$ mineralization and potential $\mathrm{N}$ surplus, whereas a $\mathrm{CO}_{2}$ increase fostered plant $\mathrm{N}$ demand that competed with microbial $\mathrm{N}_{2} \mathrm{O}$ production. While these mechanisms are part of most models, both comparison against different models show notable differences when analysing these two opposing effects. For example, Stocker et al. (2013) found that under future climate change scenarios, $\mathrm{CO}_{2}$ and climate effects are amplifying each other, in accordance with earlier model experiments (Xu-Ri et al., 2012). In LM3V$\mathrm{N}$ we find that these interactions are negative. On the other hand, simulations with O-CN (Zaehle et al., 2011) showed the effects of $\mathrm{CO}_{2}$ and climate to be approximately equal and of opposite sign for historic simulations covering the past 300 years that also include land-cover changes. They evaluated the effect of climate change as the difference between a simulation that considers both $\mathrm{CO}_{2}$ and climate and a simulation that does not consider climate change. Thus their climate effect contains both the single effect of climate and the interaction of climate with $\mathrm{CO}_{2}$. The temperature (i.e. climate) response on top of $\mathrm{CO}_{2}$ can in our simulation be calculated as the temperature effect plus the interaction effect (Fig. 8). Analysed in this fashion, LM3V-N's results are congruent with those of Zaehle et al. (2011), although we found a slightly weaker temperature effect compared to $\mathrm{CO}_{2}$. Over time, the initial response transitions into a much larger $\mathrm{CO}_{2}$ effect, while the response to temperature diminishes. This long-term response of a positive $\mathrm{CO}_{2}$ effect can be expected in a model that strongly retains $\mathrm{N}$ under limiting conditions such as LM3V-N. Retention ultimately allows build-up of $\mathrm{N}$ stocks, thereby alleviating limitation and increasing the substrate for nitrifiers and denitrifiers. This transition into a positive $\mathrm{CO}_{2}$ response was likely facilitated by up-regulation of BNF (Fig. 9), which acts to reduce ecosys- 
tem $\mathrm{N}$ deficits and plant $\mathrm{N}$ demand in the medium- to longterm. Up-regulation is expected to be much weaker or absent in models where BNF is parameterized based on evapotranspiration (Thomas et al., 2015). We realize that strong interactions as found here and elsewhere (Xu-Ri et al., 2012; Stocker et al., 2013) may also play out when other factors are considered (Brown et al., 2012), including $\mathrm{N}$ deposition, precipitation and land cover change. Therefore some of the discrepancy with other models may be caused by differences in the modelling setup. In addition, step changes in atmospheric $\mathrm{CO}_{2}$ and temperature compared to gradual and sustained increases may also lead to differences. Yet applying step changes is useful to test our conceptual understanding and may help explain the discrepancy between the previous modelling study and meta-analysis of manipulative field experiments with regard to $\mathrm{CO}_{2}$ fertilization responses (Zaehle et al., 2011; van Groenigen et al., 2011).

\section{Conclusions}

We present estimates of terrestrial soil $\mathrm{N}_{2} \mathrm{O}$ fluxes under natural vegetation (1970 to 2005) based on existing $\mathrm{N}_{2} \mathrm{O}$ emission formulations embedded into the global C-N cycle model LM3V-N. To determine the sensitivity of the modelling result to soil water (WFPS), we replaced the root zone soil water with two other derived data sets and altered the way in which WFPS is calculated. Our best estimate of modelled global soil $\mathrm{N}_{2} \mathrm{O}$ flux is 5.61-7.47 $\mathrm{TgN} \mathrm{yr}^{-1}$ (1970-2005), within the range of current understanding of soil $\mathrm{N}_{2} \mathrm{O}$ emissions, but highly sensitive to WFPS, general $\mathrm{N}$ cycling and parameterization of $\mathrm{N}_{2} \mathrm{O}$ losses through nitrification and denitrification. Comparison against field experiments suggests that LM3V-N was able to capture mean values, although site-tosite and temporal mismatches remained. Given the sensitivity of $\mathrm{N}_{2} \mathrm{O}$ emissions to WFPS, improvements in soil hydrology are likely to improve soil $\mathrm{N}_{2} \mathrm{O}$ emission estimates. As expected, we found that processes in the model that alleviate ecosystem $\mathrm{N}$ limitation, such as reduced $\mathrm{N}$ losses through fire volatilization and increased $\mathrm{N}$ inputs through higher biological nitrogen fixation (BNF) rate, enhance $\mathrm{N}_{2} \mathrm{O}$ emissions. Responses to $\mathrm{CO}_{2}$ and temperature perturbations showed differences compared to other models. In particular elevated $\mathrm{CO}_{2}$ curbs $\mathrm{N}_{2} \mathrm{O}$ emissions sharply initially, but this negative response is alleviated after a few decades, likely in conjunction with fast $\mathrm{N}$ replenishment from up-regulated BNF. Our sensitivity analysis shows that processes of the larger plantsoil $\mathrm{N}$ cycle affect fast $\mathrm{N}$ cycle processes as evidenced by the response to the fire and BNF modification. This sensitivity can lead to differences in $\mathrm{N}_{2} \mathrm{O}$ across models (e.g. in the response to $\mathrm{CO}_{2}$ and climate) even if existing nitrificationdenitrification schemes are identical. Further, our work suggests a much stronger response to warming and $\mathrm{CO}_{2}$ in tropical forests compared to extratropical forest, thus extrapolation of mostly extra-tropical field studies to the globe warrants caution. 


\section{Appendix A: Observed annual $\mathrm{N}_{2} \mathrm{O}$ fluxes data}

Annual $\mathrm{N}_{2} \mathrm{O}$ fluxes data were compiled from peer-reviewed literature. We applied simple selection criteria (see the main text) to reduce the mismatches between model outputs and field measurements, bearing in mind the gaps between complex field conditions and idealized model forcings. Latitudes (Lat) and longitudes (Lon) in Table A1 are based on model grids. 
Table A1. Observed annual $\mathrm{N}_{2} \mathrm{O}$ emission data for model comparison.

\begin{tabular}{|c|c|c|c|c|c|c|c|c|c|c|}
\hline \multirow[b]{2}{*}{ No } & \multirow[b]{2}{*}{ Country } & \multirow[b]{2}{*}{ Lon } & \multirow[b]{2}{*}{ Lat } & \multirow[b]{2}{*}{ Location } & \multirow[b]{2}{*}{ Veg Type } & \multicolumn{4}{|c|}{$\mathrm{N}_{2} \mathrm{O} \mathrm{kgN} \mathrm{ha}{ }^{-1} \mathrm{yr}^{-1}$} & \multirow[b]{2}{*}{ Reference } \\
\hline & & & & & & OBS & LM3V-N & $\mathrm{NOAH}$ & ERA & \\
\hline 1 & Australia & 133.1 & -12.3 & Douglas Daly region & Savanna & 0.02 & 0.15 & 0.25 & & Grover et al. (2012) \\
\hline 2 & Australia & 148.1 & -37.3 & Moe & Temperate forest & 0.11 & 0.58 & 0.74 & 0.72 & Khalil et al. (1990) \\
\hline 3 & Australia & 151.9 & -27.3 & South-east Queensland & Tropical forest & 0.52 & 0.01 & 0.03 & & Rowlings et al. (2012) \\
\hline 4 & Austria & 16.9 & 47.8 & Klausenleopoldsdorf & Temperate forest & 0.62 & 0.64 & 0.52 & 0.53 & Kesik et al. (2005) \\
\hline 5 & Austria & 9.4 & 47.8 & Achenkirch & Temperate forest & 0.35 & 0.54 & 0.48 & 0.47 & Kesik et al. (2005) \\
\hline 6 & Austria & 13.1 & 47.8 & Innsbruck & Temperate forest & 0.08 & 0.42 & 0.36 & 0.31 & Henrich and Haselwandter (1997) \\
\hline 7 & Austria & 16.3 & 48.2 & Schottenwald and Klausenleopoldsdorf & Temperate forest & 0.76 & 0.61 & 0.54 & 0.53 & Kitzler et al. (2006) \\
\hline 8 & Brazil & -61.9 & -2.3 & Manaus & Tropical rain forest & 1.9 & 1.6 & 1.68 & 1.56 & Luizao et al. (1989) \\
\hline 9 & Brazil & -61.9 & -2.3 & Manaus & Tropical rain forest & 1.930 & 1.71 & 1.74 & 1.55 & Keller et al. (1986) \\
\hline 10 & Brazil & -54.4 & -4.8 & East-central Amazonia & Tropical rain forest & 2.1 & 1.34 & 2.19 & 1.57 & Davidson et al. (2008) \\
\hline 11 & Brazil & -46.9 & -2.3 & Paragominas & Rainforest & 2.430 & 1.22 & 1.19 & 1.11 & Verchot et al. (1999) \\
\hline 12 & Burkina Faso & -1.9 & 10.3 & Ioba & Savanna & 0.6 & 0.03 & 1.32 & & Bruemmer et al. (2008) \\
\hline 13 & Canada & -80.6 & 50.3 & Ontario & Boreal forest & 0.04 & 0.11 & 0.14 & 0.12 & Schiller and Hastie (1996) \\
\hline 14 & Canada & -106.9 & 52.8 & Saskatchewan & Boreal forest & 0.28 & 0.01 & 0.01 & 0.01 & Simpson et al. (1997) \\
\hline 15 & Canada & -103.1 & 52.8 & Saskatchewan & Boreal forest & 0.07 & 0.21 & 0.17 & & Matson et al. (2009) \\
\hline 16 & Canada & -106.9 & 52.8 & Saskatchewan & Boreal forest & 0.09 & 0.01 & 0.01 & & Matson et al. (2009) \\
\hline 17 & Canada & -73.1 & 45.3 & Mont St. Hilaire & Temperate forest & 0.42 & 0.54 & 0.46 & & Ullah and Moore (2011) \\
\hline 18 & China & 91.9 & 35.3 & Tibet & Alpine grassland & 0.07 & 0 & 0 & 0 & Xu-Ri et al. (2012) \\
\hline 19 & China & 125.6 & 40.3 & Changbai mountain & Alpine tundra, temperate forest & 0.56 & 0.73 & 0.64 & 0.45 & Chen et al. (2000) \\
\hline 20 & China & 114.4 & 42.8 & Inner mongolia & Temperate forest & 0.73 & 0.1 & 0.14 & 0.71 & Du et al. (2006) \\
\hline 22 & China & 133.1 & 47.8 & Sanjiang Experimental Station & Freshwater marshes & 0.21 & 0.34 & 0.35 & 0.34 & Yu et al. (2007) \\
\hline 23 & Denmark & 13.1 & 55.3 & Solo & Temperate forest & 0.29 & 0.27 & 0.42 & 0.06 & Kesik et al. (2005) \\
\hline 24 & Denmark & 13.1 & 55.3 & Denmark & Temperate forest & 0.52 & 0.28 & 0.37 & 0.05 & Struwe and Kjoller (1989) \\
\hline 25 & Ecuador & -80.6 & -4.8 & Bombuscaro & Tropical forest & 0.3 & 1.02 & 0 & & Wolf et al. (2011) \\
\hline 26 & Finland & 24.4 & 60.3 & Southern & Boreal forest & 0.78 & 0.62 & 0.35 & 0.17 & Maljanen et al. (2006) \\
\hline 27 & Germany & 9.4 & 50.3 & Average & Temperate forest & 0.57 & 0.6 & 0.53 & 0.5 & Templer et al. (2012) \\
\hline 28 & Germany & 9.4 & 52.8 & Kiel & Temperate forest & 0.4 & 0.48 & 0.53 & 0.52 & Mogge et al. (1998) \\
\hline 29 & Germany & 9.4 & 47.8 & Southwest & Temperate forest & 0.93 & 0.56 & 0.51 & 0.49 & Jungkunst et al. (2004) \\
\hline 30 & Germany & 13.1 & 47.8 & Höglwald & Temperate forest & 0.41 & 0.47 & 0.4 & 0.39 & Luo et al. (2012) \\
\hline 31 & Germany & 9.4 & 52.8 & Average & Temperate forest & 0.66 & 0.44 & 0.5 & 0.5 & Brumme et al. (1999) \\
\hline 32 & Germany & 9.4 & 52.8 & Harz mountains & Mire & 0.25 & 0.48 & 0.56 & 0.52 & Tauchnitz et al. (2008) \\
\hline 34 & Indonesia & 103.1 & -2.3 & Jambi & Lowland tropical rainforest & 0.260 & 0.44 & & & Ishizuka et al. (2002) \\
\hline 35 & Indonesia & 121.9 & -2.3 & Central Sulawesi & Tropical seasonal rain forest & 0.800 & 1.73 & 2.31 & 1.7 & Purbopuspito et al. (2006) \\
\hline 36 & Indonesia & 114.4 & -2.3 & Central Kalimantan & Tropical forest & 2.51 & 2 & 2.45 & 1.73 & Takakai et al. (2006) \\
\hline 37 & Italy & 9.4 & 45.3 & P.Ticino BoscoNegri & Temperate forest & 0.18 & 1.38 & 2.8 & 1.82 & Kesik et al. (2005) \\
\hline 38 & Malaysia & 110.6 & -2.3 & Sarawak & Mixed peat swamp forest & 0.7 & 0.66 & 0.65 & 0.57 & Melling et al. (2007) \\
\hline 39 & New Zealand & 170.6 & -44.8 & New Zealand & Temperate forest & 0.01 & 1.24 & 2.84 & 1.24 & Price et al. (2004) \\
\hline 40 & Norway & 9.4 & 60.3 & Norway & Temperate forest & 0.73 & 0.52 & 0.52 & 0.38 & Sitaula et al. (1995) \\
\hline 41 & Panama & -80.6 & 7.8 & Gigante Peninsula & Tropical forests & 1.6 & 0.2 & 0.39 & 0.39 & Koehler et al. (2009) \\
\hline 42 & Sweden & 13.1 & 57.8 & Southwestern & Temperate forest & 0.07 & 1.86 & 1.67 & & Klemedtsson et al. (1997) \\
\hline 43 & Sweden & 13.1 & 57.8 & Asa experimental forest & Undrained bog & 0.65 & 0.36 & 0.45 & 0.36 & von Arnold et al. (2005) \\
\hline 44 & UK & -1.9 & 55.3 & Northumberland & Grassland & 0.3 & 0.4 & 0.5 & 0.41 & Ball et al. (2007) \\
\hline 45 & USA & -73.1 & 42.8 & Harvard forest & Mixed hardwood & 0.04 & 0.56 & 0.54 & 0.48 & Bowden et al. (1990) \\
\hline 46 & USA & -73.1 & 40.3 & New York & Temperate forest & 0.9 & 0.4 & 0.49 & 0.41 & Duxbury et al. (1982) \\
\hline 47 & USA & -80.6 & 25.3 & Florida & Marsh & 1 & 0.45 & 0 & & Duxbury et al. (1982) \\
\hline 48 & USA & -73.1 & 42.8 & New Hampshire & Temperate forest & 0.070 & 0.64 & 2.15 & & Groffman et al. (2006) \\
\hline 49 & USA & -106.9 & 35.3 & New mexico & Temperate forest & 0.06 & 0.41 & 0.51 & 0.43 & Matson et al. (1992) \\
\hline 50 & USA & -118.1 & 45.3 & Washington & Temperate shrub-steppe & 0.15 & 0.02 & 0.02 & 0.02 & Mummey et al. (1997) \\
\hline 51 & USA & -114.4 & 37.8 & Mojave desert & Perennial grasses & 0.11 & 0.02 & 0.02 & 0.02 & Billings et al. (2002) \\
\hline 52 & USA & -106.9 & 40.3 & Wyoming & Sagebrush steppe & 0.21 & 0.01 & 0.02 & 0.03 & Matson et al. (1991) \\
\hline 53 & USA & -73.1 & 45.3 & Northeastern & Temperate forest & 0.18 & 0.05 & 0.04 & 0.05 & Castro et al. (1992) \\
\hline 54 & USA & -69.4 & 45.3 & Northeastern & Temperate forest & 0.03 & 0.53 & 0.46 & 0.44 & Castro et al. (1992) \\
\hline 55 & USA & -103.1 & 40.3 & Colorado & Temperate steppe & 0.14 & 0.37 & 0.53 & 0.4 & Mosier et al. (1996) \\
\hline 56 & USA & -88.1 & 42.8 & Wisconsin & Grass & 0.040 & 0.03 & 0.05 & 0.05 & Cates and Keeney (1987) \\
\hline 57 & USA & -114.4 & 37.8 & Nevada & Mojave desert & 0.11 & 0.45 & 0.45 & & Billings et al. (2002) \\
\hline 58 & USA & -110.6 & 32.8 & Arizona & Sonoran desert & 0.4 & 0.04 & 0.04 & 0.05 & Guilbault and Matthias (1998) \\
\hline 59 & USA & -118.1 & 45.3 & Ft. Collins, Colorado & Temperate grassland & 0.12 & 0.01 & 0.03 & 0.03 & Parton et al. (1988) \\
\hline 60 & Venezuela & -61.9 & 10.3 & Venezuela & Savana & 0.73 & 0.06 & 0.07 & 0.07 & Simona et al. (2004) \\
\hline 61 & Zimbabwe & 31.9 & -17.3 & Harare & Miombo woodland savanna & 0.51 & 0.83 & 1.61 & 0.57 & Rees et al. (2005) \\
\hline
\end{tabular}


Acknowledgements. The soil moisture data used in this study were acquired as part of the mission of NASA's Earth Science Division and archived and distributed by the Goddard Earth Sciences (GES) Data and Information Services Center (DISC). We thank the European Centre for Medium-Range Weather Forecasts for providing the reanalysed soil moisture data set and the Oak Ridge National Laboratory (ORNL) Distributed Active Archive Center (DAAC) for sharing $\mathrm{N}_{2} \mathrm{O}$ observation and soil property data set. We would like to thank Matthew J. Cohen, Patrick Inglett and Jeremy W. Lichstein for their constructive comments throughout the study. We would also like to thank Lex Bouwman, Benjamin Stocker and an anonymous reviewer for constructive comments and suggestions.

Edited by: S. Zaehle

\section{References}

Andreae, M. O. and Merlet, P.: Emission of trace gases and aerosols from biomass burning, Global Biogeochem. Cy., 15, 955-966, doi:10.1029/2000gb001382, 2001.

Ball, T., Smith, K. A., and Moncrieff, J. B.: Effect of stand age on greenhouse gas fluxes from a Sitka spruce [Picea sitchensis (Bong.) Carr.] chronosequence on a peaty gley soil, Glob. Change Biol., 13, 2128-2142, doi:10.1111/j.13652486.2007.01427.x, 2007.

Banin, A.: Global budget of $\mathrm{N}_{2} \mathrm{O}$ : The role of soils and their change, Sci. Total Environ., 55, 27-38, doi:10.1016/00489697(86)90166-x, 1986.

Billings, S. A., Schaeffer, S. M., and Evans, R. D.: Trace N gas losses and $\mathrm{N}$ mineralization in Mojave desert soils exposed to elevated $\mathrm{CO}_{2}$, Soil Biol. Biochem., 34, 1777-1784, doi:10.1016/s0038-0717(02)00166-9, 2002.

Bolker, B. M., Pacala, S. W., and Parton, W. J.: Linear analysis of soil decomposition: Insights from the century model, Ecol. Appl., 8, 425-439, doi:10.2307/2641082, 1998.

Bouwman, A. F., Vanderhoek, K. W., and Olivier, J. G. J.: Uncertainties in the global source distribution of nitrous oxide, J. Geophys. Res.-Atmos., 100, 2785-2800, doi:10.1029/94jd02946, 1995.

Bowden, R. D., Steudler, P. A., Melillo, J. M., and Aber, J. D.: Annual nitrous-oxide fluxes from temperate forest soils in the northeastern United-States, J. Geophys. Res.-Atmos., 95, 1399714005, doi:10.1029/JD095iD09p13997, 1990.

Bowden, W. B.: Gaseous nitrogen emmissions from undisturbed terrestrial ecosystems: An assessment of their impacts on local and global nitrogen budgets, Biogeochemistry, 2, 249-279, doi:10.1007/bf02180161, 1986.

Braker, G. and Conrad, R.: Diversity, structure, and size of $\mathrm{N}_{2} \mathrm{O}-$ producing microbial communities in soils-what matters for their functioning?, in: Advances in Applied Microbiology, Vol 75, edited by: Laskin, A. I., Sariaslani, S., and Gadd, G. M., Advances in Applied Microbiology, 33-70, 2011.

Brown, J. R., Blankinship, J. C., Niboyet, A., van Groenigen, K. J., Dijkstra, P., Le Roux, X., Leadley, P. W., and Hungate, B. A.: Effects of multiple global change treatments on soil $\mathrm{N}_{2} \mathrm{O}$ fluxes, Biogeochemistry, 109, 85-100, doi:10.1007/s10533-0119655-2, 2012.
Bruemmer, C., Brueggemann, N., Butterbach-Bahl, K., Falk, U., Szarzynski, J., Vielhauer, K., Wassmann, R., and Papen, H.: Soilatmosphere exchange of $\mathrm{N}_{2} \mathrm{O}$ and $\mathrm{NO}$ in near-natural savanna and agricultural land in Burkina Faso (W. Africa), Ecosystems, 11, 582-600, doi:10.1007/s10021-008-9144-1, 2008.

Brumme, R., Borken, W., and Finke, S.: Hierarchical control on nitrous oxide emission in forest ecosystems, Global Biogeochem. Cy., 13, 1137-1148, doi:10.1029/1999gb900017, 1999.

Butterbach-Bahl, K., Baggs, E. M., Dannenmann, M., Kiese, R., and Zechmeister-Boltenstern, S.: Nitrous oxide emissions from soils: how well do we understand the processes and their controls?, Philos. T. R. Soc. B, 368, 20130122-20130122, doi:10.1098/rstb.2013.0122, 2013.

Castro, M. S., Steudler, P. A., Melillo, J. M., Aber, J. D., and Millham, S.: Exchange of $\mathrm{N}_{2} \mathrm{O}$ and $\mathrm{CH}_{4}$ between the atmosphere and soils in spruce-fir forests in the northeastern United-States, Biogeochemistry, 18, 119-135, doi:10.1007/bf00003273, 1992.

Cates Jr., R. L., and Keeney, D. R.: Nitrous oxide emission from native and reestablished prairies in southern Wisconsin, American Midland Naturalist, 117, 35-42, 1987.

Chen, G. X., Huang, B., Xu, H., Zhang, Y., Huang, G. H., Yu, K. W., Hou, A. X., Du, R., Han, S. J., and VanCleemput, O.: Nitrous oxide emissions from terrestrial ecosystems in China, Chemosphere: Global Change Science, 2, 373-378, 2000.

Ciais, P., Sabine, C., Bala, G., Bopp, L., Brovkin, V., Canadell, J., Chhabra, A., DeFries, R., Galloway, J., Heimann, M., Jones, C., Quéré, C. L., Myneni, R. B., Piao, S., and Thornton, P.: Carbon and Other Biogeochemical Cycles, in: Climate Change 2013: The Physical Science Basis. Contribution of Working Group I to the Fifth Assessment Report of the Intergovernmental Panel on Climate Change, edited by: Stocker, T. F., Qin, D., Plattner, G.-K., Tignor, M., Allen, S. K., Boschung, J., Nauels, A., Xia, Y., Bex, V., and Midgley, P. M., Cambridge University Press, Cambridge, United Kingdom and New York, NY, USA, 465570, 2013.

Cleveland, C. C., Townsend, A. R., Schimel, D. S., Fisher, H., Howarth, R. W., Hedin, L. O., Perakis, S. S., Latty, E. F., Von Fischer, J. C., Elseroad, A., and Wasson, M. F.: Global patterns of terrestrial biological nitrogen $\left(\mathrm{N}_{2}\right)$ fixation in natural ecosystems, Global Biogeochem. Cy., 13, 623-645, doi:10.1029/1999gb900014, 1999.

Collatz, G. J., Ball, J. T., Grivet, C., and Berry, J. A.: Physiological and environmental regulation of stomatal conductance, photosynthesis and transpiration: a model that includes a laminar boundary layer, Agr. Forest Meteorol., 54, 107-136, doi:10.1016/0168-1923(91)90002-8, 1991.

Collatz, G. J., Ribas-Carbo, M., and Berry, J. A.: Coupled photosynthesis-stomatal conductance model for leaves of $\mathrm{C} 4$ plants, Aust. J. Plant Physiol., 19, 519-538, 1992.

Davidson, E. A.: The contribution of manure and fertilizer nitrogen to atmospheric nitrous oxide since 1860, Nat. Geosci., 2, 659662, doi:10.1038/ngeo608, 2009.

Davidson, E. A. and Trumbore, S. E.: Gas diffusivity and production of $\mathrm{CO}_{2}$ in deep soils of the eastern Amazon, Tellus B, 47, 550 565, doi:10.1034/j.1600-0889.47.issue5.3.x, 1995.

Davidson, E. A., Ishida, F. Y., and Nepstad, D. C.: Effects of an experimental drought on soil emissions of carbon dioxide, methane, nitrous oxide, and nitric oxide in a moist tropical 
forest, Glob. Change Biol., 10, 718-730, doi:10.1111/j.13652486.2004.00762.x, 2004.

Davidson, E. A., Nepstad, D. C., Ishida, F. Y., and Brando, P. M.: Effects of an experimental drought and recovery on soil emissions of carbon dioxide, methane, nitrous oxide, and nitric oxide in a moist tropical forest, Glob. Change Biol., 14, 2582-2590, doi:10.1111/j.1365-2486.2008.01694.x, 2008.

Dee, D. P., Uppala, S. M., Simmons, A. J., Berrisford, P., Poli, P., Kobayashi, S., Andrae, U., Balmaseda, M. A., Balsamo, G., Bauer, P., Bechtold, P., Beljaars, A. C. M., van de Berg, L., Bidlot, J., Bormann, N., Delsol, C., Dragani, R., Fuentes, M., Geer, A. J., Haimberger, L., Healy, S. B., Hersbach, H., Holm, E. V., Isaksen, L., Kallberg, P., Koehler, M., Matricardi, M., McNally, A. P., Monge-Sanz, B. M., Morcrette, J. J., Park, B. K., Peubey, C., de Rosnay, P., Tavolato, C., Thepaut, J. N., and Vitart, F.: The ERA-Interim reanalysis: configuration and performance of the data assimilation system, Q. J. Roy. Meteor. Soc., 137, 553-597, doi:10.1002/qj.828, 2011.

Del Grosso, S. J., Parton, W. J., Mosier, A. R., Ojima, D. S., Kulmala, A. E., and Phongpan, S.: General model for $\mathrm{N}_{2} \mathrm{O}$ and $\mathrm{N}_{2}$ gas emissions from soils due to dentrification, Global Biogeochem. Cy., 14, 1045-1060, 2000.

Dentener, F., Drevet, J., Lamarque, J. F., Bey, I., Eickhout, B., Fiore, A. M., Hauglustaine, D., Horowitz, L. W., Krol, M., Kulshrestha, U. C., Lawrence, M., Galy-Lacaux, C., Rast, S., Shindell, D., Stevenson, D., Van Noije, T., Atherton, C., Bell, N., Bergman, D., Butler, T., Cofala, J., Collins, B., Doherty, R., Ellingsen, K., Galloway, J., Gauss, M., Montanaro, V., Mueller, J. F., Pitari, G., Rodriguez, J., Sanderson, M., Solmon, F., Strahan, S., Schultz, M., Sudo, K., Szopa, S., and Wild, O.: Nitrogen and sulfur deposition on regional and global scales: A multimodel evaluation, Global Biogeochem. Cy., 20, Gb4003, doi:10.1029/2005gb002672, 2006.

Dentener, F. J. and Crutzen, P. J.: A three-dimensional model of the global ammonia cycle, J. Atmos. Chem., 19, 331-369, doi:10.1007/bf00694492, 1994.

Dijkstra, F. A., Prior, S. A., Runion, G. B., Torbert, H. A., Tian, H., Lu, C., and Venterea, R. T.: Effects of elevated carbon dioxide and increased temperature on methane and nitrous oxide fluxes: evidence from field experiments, Front. Ecol. Environ., 10, 520527, doi:10.1890/120059, 2012.

Du, R., Lu, D. and Wang, G.: Diurnal, seasonal, and interannual variations of $\mathrm{N}_{2} \mathrm{O}$ fluxes from native semi-arid grassland soils of inner mongolia, Soil Biol. Biochem., 38, 3474-3482, doi:10.1016/j.soilbio.2006.06.012, 2006.

Duxbury, J. M., Bouldin, D. R., Terry, R. E., and Tate, R. L.: Emissions of nitrous-oxide from soils, Nature, 298, 462-464, doi:10.1038/298462a0, 1982.

Farquhar, G. D., Caemmerer, S. V., and Berry, J. A.: A biochemical model of photosynthetic $\mathrm{CO}_{2}$ assimilation in leaves of $\mathrm{C}_{3}$ species, Planta, 149, 78-90, doi:10.1007/bf00386231, 1980.

Firestone, M. K. and Davidson, E. A.: Microbiological basis of NO and $\mathrm{N}_{2} \mathrm{O}$ production and consumption in soil, Exchange of trace gases between terrestrial ecosystems and the atmosphere, edited by: Andreae, M. O. and Schimel, D. S., 7-21, 1989.

Forster, P., Ramaswamy, V., Artaxo, P., Berntsen, T., Betts, R., Fahey, D. W., Haywood, J., Lean, J., Lowe, D. C., Myhre, G., Nganga, J., Prinn, R., Raga, G., Schulz, M., and Dorland, R. V.: Changes in Atmospheric Constituents and in Radiative Forc- ing, in: Climate Change 2007: The Physical Science Basis. Contribution of Working Group I to the Fourth Assessment Report of the Intergovernmental Panel on Climate Change, edited by: Solomon, S., Qin, D., Manning, M., Chen, Z., Marquis, M., Averyt, K. B., Tignor, M., and Miller, H. L., Cambridge University Press, Cambridge, United Kingdom and New York, NY, USA, 129-234, 2007.

Galloway, J. N., Aber, J. D., Erisman, J. W., Seitzinger, S. P., Howarth, R. W., Cowling, E. B., and Cosby, B. J.: The nitrogen cascade, Bioscience, 53, 341-356, doi:10.1641/00063568(2003)053[0341:tnc]2.0.co;2, 2003.

Gerber, S. and Brookshire, E. N. J.: Scaling of physical constraints at the root-soil interface to macroscopic patterns of nutrient retention in ecosystems, Am. Nat., 183, 418-430, doi:10.1086/674907, 2014.

Gerber, S., Hedin, L. O., Oppenheimer, M., Pacala, S. W., and Shevliakova, E.: Nitrogen cycling and feedbacks in a global dynamic land model, Global Biogeochem. Cy., 24, GB1001, doi:10.1029/2008gb003336, 2010.

Gerber, S., Hedin, L. O., Keel, S. G., Pacala, S. W., and Shevliakova, E.: Land use change and nitrogen feedbacks constrain the trajectory of the land carbon sink, Geophys. Res. Lett., 40, 5218-5222, doi:10.1002/grl.50957, 2013.

Goodroad, L. L, and Keeney, D. R.: Nitrous oxide emission from forest, marsh, and prairie ecosystems, J. Environ. Qual., 13, 448452, 1984.

Green, P. A., Vorosmarty, C. J., Meybeck, M., Galloway, J. N., Peterson, B. J., and Boyer, E. W.: Pre-industrial and contemporary fluxes of nitrogen through rivers: a global assessment based on typology, Biogeochemistry, 68, 71-105, doi:10.1023/b:biog.0000025742.82155.92, 2004.

Groffman, P. M., Hardy, J. P., Driscoll, C. T., and Fahey, T. J.: Snow depth, soil freezing, and fluxes of carbon dioxide, nitrous oxide and methane in a northern hardwood forest, Glob. Change Biol., 12, 1748-1760, doi:10.1111/j.1365-2486.2006.01194.x, 2006.

Grover, S. P. P., Livesley, S. J., Hutley, L. B., Jamali, H., Fest, B., Beringer, J., Butterbach-Bahl, K., and Arndt, S. K.: Land use change and the impact on greenhouse gas exchange in north Australian savanna soils, Biogeosciences, 9, 423-437, doi:10.5194/bg-9-423-2012, 2012.

Guilbault, M. R. and Matthias, A. D.: Emissions of $\mathrm{N}_{2} \mathrm{O}$ from Sonoran Desert and effluent-irrigated grass ecosytems, J. Arid Environ., 38, 87-98, doi:10.1006/jare.1997.0300, 1998.

Heinen, M.: Simplified denitrification models: Overview and properties, Geoderma, 133, 444-463, doi:10.1016/j.geoderma.2005.06.010, 2006.

Henrich, M. and Haselwandter, K.: Denitrification and gaseous nitrogen losses from an acid spruce forest soil, Soil Biol. Biochem., 29, 1529-1537, doi:10.1016/s0038-0717(97)00010-2, 1997.

Hirsch, A. I., Michalak, A. M., Bruhwiler, L. M., Peters, W., Dlugokencky, E. J., and Tans, P. P.: Inverse modeling estimates of the global nitrous oxide surface flux from 1998-2001, Global Biogeochem. Cy., 20, GB1008, doi:10.1029/2004gb002443, 2006.

Ishizuka, S., Tsuruta, H., and Murdiyarso, D.: An intensive field study on $\mathrm{CO}_{2}, \mathrm{CH}_{4}$, and $\mathrm{N}_{2} \mathrm{O}$ emissions from soils at four landuse types in Sumatra, Indonesia, Global Biogeochem. Cy., 16, GB1049, doi:10.1029/2001gb001614, 2002.

Jungkunst, H. F., Fiedler, S., and Stahr, K.: $\mathrm{N}_{2} \mathrm{O}$ emissions of a mature Norway spruce (Picea abies) stand in the black forest (south- 
west Germany) as differentiated by the soil pattern, J. Geophys. Res.-Atmos., 109, D07302, doi:10.1029/2003jd004344, 2004.

Keeling, R. F., Piper, S. C., Bollenbacher, A. F., and Walker, J. S.: Atmospheric $\mathrm{CO}_{2}$ records from sites in the SIO air sampling network, in Trends: A compendium of data on global change. Carbon Dioxide Information Analysis Center, Oak Ridge National Laboratory, U.S. Department of Energy, Oak Ridge, Tenn., USA, available from: http://cdiac.ornl.gov/trends/co2/sio-mlo. html (last access: 13 August 2010), 2009.

Keller, M., Kaplan, W. A., and Wofsy, S. C.: Emissions of $\mathrm{N}_{2} \mathrm{O}$, $\mathrm{CH}_{4}$ and $\mathrm{CO}_{2}$ from tropical forest soils, J. Geophys. Res.Atmos., 91, 1791-1802, doi:10.1029/JD091iD11p11791, 1986.

Kesik, M., Ambus, P., Baritz, R., Brüggemann, N., ButterbachBahl, K., Damm, M., Duyzer, J., Horváth, L., Kiese, R., Kitzler, B., Leip, A., Li, C., Pihlatie, M., Pilegaard, K., Seufert, S., Simpson, D., Skiba, U., Smiatek, G., Vesala, T., and ZechmeisterBoltenstern, S.: Inventories of $\mathrm{N}_{2} \mathrm{O}$ and $\mathrm{NO}$ emissions from European forest soils, Biogeosciences, 2, 353-375, doi:10.5194/bg2-353-2005, 2005.

Khalil, K., Mary, B., and Renault, P.: Nitrous oxide production by nitrification and denitrification in soil aggregates as affected by $\mathrm{O}_{2}$ concentration, Soil Biol. Biochem., 36, 687-699, doi:10.1016/j.soilbio.2004.01.004, 2004.

Khalil, M. A. K., Rasmussen, R. A., French, J. R. J., and Holt, J. A.: The influence of termites on atmospheric trace gases: $\mathrm{CH}_{4}, \mathrm{CO}_{2}$, $\mathrm{CHCl}_{3}, \mathrm{~N}_{2} \mathrm{O}, \mathrm{CO}, \mathrm{H}_{2}$, and light-hydrocarbons, J. Geophys. Res.Atmos., 95, 3619-3634, doi:10.1029/JD095iD04p03619, 1990.

Kitzler, B., Zechmeister-Boltenstern, S., Holtermann, C., Skiba, U., and Butterbach-Bahl, K.: Nitrogen oxides emission from two beech forests subjected to different nitrogen loads, Biogeosciences, 3, 293-310, doi:10.5194/bg-3-293-2006, 2006.

Klemedtsson, L., Klemedtsson, A. K., Moldan, F., and Weslien, P.: Nitrous oxide emission from Swedish forest soils in relation to liming and simulated increased N-deposition, Biol. Fert. Soil., 25, 290-295, doi:10.1007/s003740050317, 1997.

Koehler, B., Corre, M. D., Veldkamp, E., Wullaert, H., and Wright, S. J.: Immediate and long-term nitrogen oxide emissions from tropical forest soils exposed to elevated nitrogen input, Glob. Change Biol., 15, 2049-2066, doi:10.1111/j.13652486.2008.01826.x, 2009.

Li, C. S., Frolking, S., and Frolking, T. A.: A model of nitrous-oxide evolution from soil driven by rainfall events 1 . model structure and sensitivity, J. Geophys. Res.-Atmos., 97, 9759-9776, 1992.

Li, C. S., Aber, J., Stange, F., Butterbach-Bahl, K., and Papen, H.: A process-oriented model of $\mathrm{N}_{2} \mathrm{O}$ and $\mathrm{NO}$ emissions from forest soils: 1. Model development, J. Geophys. Res.-Atmos., 105, 4369-4384, doi:10.1029/1999jd900949, 2000.

Linn, D. M. and Doran, J. W.: Effect of water-filled pore space on carbon dioxide and nitrous oxide production in tilled and nontilled soils, Soil Sci. Soc. Am. J., 48, 1267-1272, 1984.

Luizao, F., Matson, P., Livingston, G., Luizao, R., and Vitousek, P.: Nitrous oxide flux following tropical land clearing, Global Biogeochem. Cy., 3, 281-285, doi:10.1029/GB003i003p00281, 1989.

Luo, G. J., Brüggemann, N., Wolf, B., Gasche, R., Grote, R., and Butterbach-Bahl, K.: Decadal variability of soil $\mathrm{CO}_{2}, \mathrm{NO}$, $\mathrm{N}_{2} \mathrm{O}$, and $\mathrm{CH}_{4}$ fluxes at the Höglwald Forest, Germany, Biogeosciences, 9, 1741-1763, doi:10.5194/bg-9-1741-2012, 2012.
Maljanen, M., Jokinen, H., Saari, A., Strommer, R., and Martikainen, P. J.: Methane and nitrous oxide fluxes, and carbon dioxide production in boreal forest soil fertilized with wood ash and nitrogen, Soil Use Manage., 22, 151-157, doi:10.1111/j.1475-2743.2006.00029.x, 2006.

Matson, A., Pennock, D., and Bedard-Haughn, A.: Methane and nitrous oxide emissions from mature forest stands in the boreal forest, Saskatchewan, Canada, Forest Ecol. Manag., 258, 10731083, doi:10.1016/j.foreco.2009.05.034, 2009.

Matson, P. A., Volkmann, C., Coppinger, K., and Reiners, W. A.: Annual nitrous-oxide flux and soil-nitrogen characteristics in sagebrush steppe ecosystems, Biogeochemistry, 14, 1-12, 1991.

Matson, P. A., Gower, S. T., Volkmann, C., Billow, C., and Grier, C. C.: Soil nitrogen cycling and nitrous oxide flux in a Rocky Mountain Douglas-fir forest: effects of fertilization, irrigation and carbon addition, Biogeochemistry, 18, 101-117, doi:10.1007/bf00002705, 1992.

Melling, L., Hatano, R., and Goh, K. J.: Nitrous oxide emissions from three ecosystems in tropical peatland of Sarawak, Malaysia, Soil Sci. Plant Nutr., 53, 792-805, doi:10.1111/j.17470765.2007.00196.x, 2007.

Milly, P. C. D. and Shmakin, A. B.: Global modeling of land water and energy balances. Part I: the land dynamics (LaD) model, J. Hydrometeorol., 3, 283-299, doi:10.1175/15257541(2002)003<0283: gmolwa> 2.0.co; 2, 2002.

Milly, P. C. D., Malyshev, S. L., Shevliakova, E., Dunne, K. A., Findell, K. L., Gleeson, T., Liang, Z., Phillipps, P., Stouffer, R. J., and Swenson, S.: An enhanced model of land water and energy for global hydrologic and Earth-System studies, J. Hydrometeorol., 15, 1739-1761, 2014.

Mogge, B., Kaiser, E. A., and Munch, J. C.: Nitrous oxide emissions and denitrification $\mathrm{N}$-losses from forest soils in the Bornhöved Lake region (Northern Germany), Soil Biol. Biochem., 30, 703710, doi:10.1016/s0038-0717(97)00205-8, 1998.

Morishita, T., Sakata, T., Takahashi, M., Ishizuka, S., Mizoguchi, T., Inagaki, Y., Terazawa, K., Sawata, S., Igarashi, M., Yasuda, H., Koyama, Y., Suzuki, Y., Toyota, N., Muro, M., Kinjo, M., Yamamoto, H., Ashiya, D., Kanazawa, Y., Hashimoto, T., and Umata, H.: Methane uptake and nitrous oxide emission in Japanese forest soils and their relationship to soil and vegetation types, Soil Sci. Plant Nutr., 53, 678-691, doi:10.1111/j.17470765.2007.00181.x, 2007.

Mosier, A. R., Parton, W. J., Valentine, D. W., Ojima, D. S., Schimel, D. S., and Delgado, J. A.: $\mathrm{CH}_{4}$ and $\mathrm{N}_{2} \mathrm{O}$ fluxes in the Colorado shortgrass steppe 1. Impact of landscape and nitrogen addition, Global Biogeochem. Cy., 10, 387-399, doi:10.1029/96gb01454, 1996.

Mummey, D. L., Smith, J. L., and Bolton, H.: Small-scale spatial and temporal variability of $\mathrm{N}_{2} \mathrm{O}$ flux from a shrub-steppe ecosystem, Soil Biol. Biochem., 29, 1699-1706, doi:10.1016/s00380717(97)00077-1, 1997.

Parton, W. J., Mosier, A. R., and Schimel, D. S.: Rates and pathways of nitrous-oxide production in a shortgrass steppe, Biogeochemistry, 6, 45-58, 1988.

Parton, W. J., Mosier, A. R., Ojima, D. S., Valentine, D. W., Schimel, D. S., Weier, K., and Kulmala, A. E.: Generalized model for $\mathrm{N}_{2}$ and $\mathrm{N}_{2} \mathrm{O}$ production from nitrification and denitrification, Global Biogeochem. Cy., 10, 401-412, doi:10.1029/96gb01455, 1996. 
Parton, W. J., Holland, E. A., Del Grosso, S. J., Hartman, M. D., Martin, R. E., Mosier, A. R., Ojima, D. S., and Schimel, D. S.: Generalized model for $\mathrm{NO}_{x}$ and $\mathrm{N}_{2} \mathrm{O}$ emissions from soils, J. Geophys. Res.-Atmos., 106, 17403-17419, doi:10.1029/2001jd900101, 2001.

Potter, C. S. and Klooster, S. A.: Interannual variability in soil trace gas $\left(\mathrm{CO}_{2}, \mathrm{~N}_{2} \mathrm{O}, \mathrm{NO}\right)$ fluxes and analysis of controllers on regional to global scales, Global Biogeochem. Cy., 12, 621-635, doi:10.1029/98gb02425, 1998.

Potter, C. S., Matson, P. A., Vitousek, P. M., and Davidson, E. A.: Process modeling of controls on nitrogen trace gas emissions from soils worldwide, J. Geophys. Res.-Atmos., 101, 13611377, doi:10.1029/95jd02028, 1996.

Price, S. J., Sherlock, R. R., Kelliher, F. M., McSeveny, T. M., Tate, K. R., and Condron, L. M.: Pristine new zealand forest soil is a strong methane sink, Glob. Change Biol., 10, 16-26, doi:10.1046/j.1529-8817.2003.00710x, 2004.

Purbopuspito, J., Veldkamp, E., Brumme, R., and Murdiyarso, D.: Trace gas fluxes and nitrogen cycling along an elevation sequence of tropical montane forests in Central Sulawesi, Indonesia, Global Biogeochem. Cy., 20, GB3010, doi:10.1029/2005gb002516, 2006.

Ravishankara, A. R., Daniel, J. S., and Portmann, R. W.: Nitrous oxide $\left(\mathrm{N}_{2} \mathrm{O}\right)$ : The dominant ozone-depleting substance emitted in the 21st century, Science, 326, 123-125, doi:10.1126/science.1176985, 2009.

Rees, R. M., Wuta, M., Furley, P. A., and Li, C. S.: Nitrous oxide fluxes from savanna (miombo) woodlands in Zimbabwe, J. Biogeogr., 33, 424-437, 2005.

Rodell, M., Houser, P. R., Jambor, U., Gottschalck, J., Mitchell, K., Meng, C. J., Arsenault, K., Cosgrove, B., Radakovich, J., Bosilovich, M., Entin, J. K., Walker, J. P., Lohmann, D., and Toll, D.: The global land data assimilation system, B.e Am. Meteorol. Soc., 85, 381-394, doi:10.1175/bams-85-3-381, 2004.

Rowlings, D. W., Grace, P. R., Kiese, R., and Weier, K. L.: Environmental factors controlling temporal and spatial variability in the soil-atmosphere exchange of $\mathrm{CO}_{2}, \mathrm{CH}_{4}$ and $\mathrm{N}_{2} \mathrm{O}$ from an Australian subtropical rainforest, Glob. Change Biol., 18, 726-738, doi:10.1111/j.1365-2486.2011.02563.x, 2012.

Saikawa, E., Schlosser, C. A., and Prinn, R. G.: Global modeling of soil nitrous oxide emissions from natural processes, Global Biogeochem. Cy., 27, 972-989, doi:10.1002/gbc.20087, 2013.

Schiller, C. L. and Hastie, D. R.: Nitrous oxide and methane fluxes from perturbed and unperturbed boreal forest sites in northern Ontario, J. Geophys. Res.-Atmos., 101, 22767-22774, doi:10.1029/96jd01620, 1996.

Schlesinger, W. H.: On the fate of anthropogenic nitrogen, P. Natl. Acad. Sci. USA, 106, 203-208, doi:10.1073/pnas.0810193105, 2009.

Schmidt, J., Seiler, W., and Conrad, R.: Emission of nitrous oxide from temperate forest soils into the atmosphere, J. Atmos. Chem., 6, 95-115, doi:10.1007/bf00048334, 1988.

Schwalm, C. R., Williams, C. A., Schaefer, K., Baker, I., Collatz, G. J., and Rödenbeck, C.: Does terrestrial drought explain global $\mathrm{CO}_{2}$ flux anomalies induced by El Niño?, Biogeosciences, 8, 2493-2506, doi:10.5194/bg-8-2493-2011, 2011.

Seneviratne, S. I., Corti, T., Davin, E. L., Hirschi, M., Jaeger, E. B., Lehner, I., Orlowsky, B., and Teuling, A. J.: Investigating soil moisture-climate interactions in a changing climate: A review, Earth-Sci. Rev., 99, 125-161, doi:10.1016/j.earscirev.2010.02.004, 2010.

Sheffield, J., Goteti, G., and Wood, E. F.: Development of a 50-year high-resolution global dataset of meteorological forcings for land surface modeling, J. Climate, 19, 3088-3111, doi:10.1175/jcli3790.1, 2006.

Shevliakova, E., Pacala, S. W., Malyshev, S., Hurtt, G. C., Milly, P. C. D., Caspersen, J. P., Sentman, L. T., Fisk, J. P., Wirth, C., and Crevoisier, C.: Carbon cycling under 300 years of land use change: Importance of the secondary vegetation sink, Global Biogeochem. Cy., 23, doi:10.1029/2007gb003176, 2009.

Simona, C., Ariangelo, D. P. R., John, G., Nina, N., Ruben, M., and Jose, S. J.: Nitrous oxide and methane fluxes from soils of the Orinoco savanna under different land uses, Glob. Change Biol., 10, 1947-1960, doi:10.1111/j.1365-2486.2004.00871.x, 2004.

Simpson, I. J., Edwards, G. C., Thurtell, G. W., den Hartog, G., Neumann, H. H., and Staebler, R. M.: Micrometeorological measurements of methane and nitrous oxide exchange above a boreal aspen forest, J. Geophys. Res.-Atmos., 102, 29331-29341, doi:10.1029/97jd03181, 1997.

Sitaula, B. K., Bakken, L. R., and Abrahamsen, G.: N-fertilization and soil acidification effects on $\mathrm{N}_{2} \mathrm{O}$ and $\mathrm{CO}_{2}$ emission from temperate pine forest soil, Soil Biol. Biochem., 27, 1401-1408, doi:10.1016/0038-0717(95)00078-s, 1995.

Smith, B., Wårlind, D., Arneth, A., Hickler, T., Leadley, P., Siltberg, J., and Zaehle, S.: Implications of incorporating $\mathrm{N}$ cycling and $\mathrm{N}$ limitations on primary production in an individualbased dynamic vegetation model, Biogeosciences, 11, 20272054, doi:10.5194/bg-11-2027-2014, 2014.

Sousa Neto, E., Carmo, J. B., Keller, M., Martins, S. C., Alves, L. F., Vieira, S. A., Piccolo, M. C., Camargo, P., Couto, H. T. Z., Joly, C. A., and Martinelli, L. A.: Soil-atmosphere exchange of nitrous oxide, methane and carbon dioxide in a gradient of elevation in the coastal Brazilian Atlantic forest, Biogeosciences, 8, 733-742, doi:10.5194/bg-8-733-2011, 2011.

Stehfest, E., and Bouwman, L.: $\mathrm{N}_{2} \mathrm{O}$ and $\mathrm{NO}$ emission from agricultural fields and soils under natural vegetation: summarizing available measurement data and modeling of global annual emissions, Nutr. Cycl. Agroecosys., 74, 207-228, doi:10.1007/s10705-0069000-7, 2006.

Stocker, B. D., Roth, R., Joos, F., Spahni, R., Steinacher, M., Zaehle, S., Bouwman, L., Xu-Ri, and Prentice, I. C.: Multiple greenhouse-gas feedbacks from the land biosphere under future climate change scenarios, Nature Climate Change, 3, 666-672, doi:10.1038/nclimate1864, 2013.

Struwe, S. and Kjoller, A.: Field determination of denitrification in water-logged forest soils, FEMS Microbiol. Ecol., 62, 71-78, 1989.

Syakila, A. and Kroeze, C.: The global nitrous oxide budget revisited, Greenhouse Gas Measurement and Management, 1, 17-26, doi:10.3763/ghgmm.2010.0007, 2011.

Takakai, F., Morishita, T., Hashidoko, Y., Darung, U., Kuramochi, K., Dohong, S., Limin, S. H., and Hatano, R.: Effects of agricultural land-use change and forest fire on $\mathrm{N}_{2} \mathrm{O}$ emission from tropical peatlands, Central Kalimantan, Indonesia, Soil Sci. Plant Nutr., 52, 662-674, doi:10.1111/j.17470765.2006.00084.x, 2006.

Tauchnitz, N., Brumme, R., Bernsdorf, S., and Meissner, R.: Nitrous oxide and methane fluxes of a pristine slope mire in the 
German National Park Harz Mountains, Plant Soil, 303, 131138, doi:10.1007/s11104-007-9493-0, 2008.

Templer, P. H., Mack, M. C., Chapin, F. S., III, Christenson, L. M., Compton, J. E., Crook, H. D., Currie, W. S., Curtis, C. J., Dail, D. B., D’Antonio, C. M., Emmett, B. A., Epstein, H. E., Goodale, C. L., Gundersen, P., Hobbie, S. E., Holland, K., Hooper, D. U., Hungate, B. A., Lamontagne, S., Nadelhoffer, K. J., Osenberg, C. W., Perakis, S. S., Schleppi, P., Schimel, J., Schmidt, I. K., Sommerkorn, M., Spoelstra, J., Tietema, A., Wessel, W. W., and Zak, D. R.: Sinks for nitrogen inputs in terrestrial ecosystems: A meta-analysis of ${ }^{15} \mathrm{~N}$ tracer field studies, Ecology, 93, 18161829, 2012.

Thomas, R. Q., Brookshire, E. N. J., and Gerber, S.: Nitrogen limitation on land: how can it occur in Earth system models?, Glob. Change Biol., 21, 1777-1793, doi:10.1111/gcb.12813, 2015.

Thompson, R. L., Chevallier, F., Crotwell, A. M., Dutton, G., Langenfelds, R. L., Prinn, R. G., Weiss, R. F., Tohjima, Y., Nakazawa, T., Krummel, P. B., Steele, L. P., Fraser, P., O'Doherty, S., Ishijima, K., and Aoki, S.: Nitrous oxide emissions 1999 to 2009 from a global atmospheric inversion, Atmos. Chem. Phys., 14, 1801-1817, doi:10.5194/acp-14-18012014, 2014.

Thornton, P. E., Lamarque, J.-F., Rosenbloom, N. A., and Mahowald, N. M.: Influence of carbon-nitrogen cycle coupling on land model response to $\mathrm{CO}_{2}$ fertilization and climate variability, Global Biogeochem. Cy., 21, Gb4018, doi:10.1029/2006gb002868, 2007.

Ullah, S. and Moore, T. R.: Biogeochemical controls on methane, nitrous oxide, and carbon dioxide fluxes from deciduous forest soils in eastern Canada, J. Geophys. Res.-Biogeo., 116, GB3010, doi:10.1029/2010jg001525, 2011.

van Groenigen, K. J., Osenberg, C. W., and Hungate, B. A.: Increased soil emissions of potent greenhouse gases under increased atmospheric $\mathrm{CO}_{2}$, Nature, 475, 214-121, doi:10.1038/nature10176, 2011.

Verchot, L. V., Davidson, E. A., Cattanio, J. H., Ackerman, I. L., Erickson, H. E., and Keller, M.: Land use change and biogeochemical controls of nitrogen oxide emissions from soils in eastern Amazonia, Global Biogeochem. Cy., 13, 31-46, doi:10.1029/1998gb900019, 1999.

von Arnold, K., Nilsson, M., Hanell, B., Weslien, P., and Klemedtsson, L.: Fluxes of $\mathrm{CO}_{2}, \mathrm{CH}_{4}$ and $\mathrm{N}_{2} \mathrm{O}$ from drained organic soils in deciduous forests, Soil Biol. Biochem., 37, 1059-1071, doi:10.1016/j.soilbio.2004.11.004, 2005.

Wei, Y., Liu, S., Huntzinger, D.N., Michalak, A.M., Viovy, N., Post, W.M., Schwalm, C.R., Schaefer, K., Jacobson, A.R., Lu, C., Tian, H., Ricciuto, D.M., Cook, R.B., Mao,J., and Shi, X.: NACP MsTMIP: Global and North American Driver Data for MultiModel Intercomparison, Data set, Oak Ridge National Laboratory Distributed Active Archive Center, Oak Ridge, Tennessee, USA, available at: http://dx.doi.org/10.3334/ORNLDAAC/1220, last access: 2 May 2014.
Werner, C., Butterbach-Bahl, K., Haas, E., Hickler, T., and Kiese, R.: A global inventory of $\mathrm{N}_{2} \mathrm{O}$ emissions from tropical rainforest soils using a detailed biogeochemical model, Global Biogeochem. Cy., 21, GB3010, doi:10.1029/2006gb002909, 2007.

Wolf, K., Veldkamp, E., Homeier, J., and Martinson, G. O.: Nitrogen availability links forest productivity, soil nitrous oxide and nitric oxide fluxes of a tropical montane forest in southern Ecuador, Global Biogeochem. Cy., 25, GB4009, doi:10.1029/2010gb003876, 2011.

$\mathrm{Xu}-\mathrm{Ri}$ and Prentice, I. C.: Terrestrial nitrogen cycle simulation with a dynamic global vegetation model, Glob. Change Biol., 14, 1745-1764, doi:10.1111/j.1365-2486.2008.01625.x, 2008.

Xu-Ri, Wang, Y. S., Zheng, X. H., Ji, B. M., and Wang, M. X.: A comparison between measured and modeled $\mathrm{N}_{2} \mathrm{O}$ emissions from Inner Mongolian semi-arid grassland, Plant Soil, 255, 513528, 2003.

Xu-Ri, Prentice, I. C., Spahni, R., and Niu, H. S.: Modelling terrestrial nitrous oxide emissions and implications for climate feedback, New Phytol., 196, 472-488, doi:10.1111/j.14698137.2012.04269.x, 2012.

Yienger, J. J. and Levy, H.: Empirical model of global soil-biogenic $\mathrm{NO}_{x}$ emissions, J. Geophys. Res.-Atmos., 100, 11447-11464, doi:10.1029/95jd00370, 1995.

Yu, J., Liu, J., Wang, J., Sun, W., Patrick, W. H., Jr., and Meixner, F. X.: Nitrous oxide emission from deyeuxia angustifolia freshwater marsh in northeast China, Environ. Manage., 40, 613-622, doi:10.1007/s00267-006-0349-9, 2007.

Zaehle, S. and Friend, A. D.: Carbon and nitrogen cycle dynamics in the O-CN land surface model: 1. Model description, site-scale evaluation, and sensitivity to parameter estimates, Global Biogeochem. Cy., 24, GB1005, doi:10.1029/2009gb003521, 2010.

Zaehle, S. and Dalmonech, D.: Carbon-nitrogen interactions on land at global scales: current understanding in modelling climate biosphere feedbacks, Current Opinion in Environmental Sustainability, 3, 311-320, doi:10.1016/j.cosust.2011.08.008, 2011.

Zaehle, S., Friend, A. D., Friedlingstein, P., Dentener, F., Peylin, P., and Schulz, M.: Carbon and nitrogen cycle dynamics in the O$\mathrm{CN}$ land surface model: 2 . Role of the nitrogen cycle in the historical terrestrial carbon balance, Global Biogeochem. Cy., 24, GB1006, doi:10.1029/2009gb003522, 2010.

Zaehle, S., Ciais, P., Friend, A. D., and Prieur, V.: Carbon benefits of anthropogenic reactive nitrogen offset by nitrous oxide emissions, Nat. Geosci., 4, 601-605, doi:10.1038/ngeo1207, 2011.

Zhuang, Q., Lu, Y., and Chen, M.: An inventory of global $\mathrm{N}_{2} \mathrm{O}$ emissions from the soils of natural terrestrial ecosystems, Atmos. Environ., 47, 66-75, doi:10.1016/j.atmosenv.2011.11.036, 2012. 